\title{
CELS
}

CELSI Di scussi on Paper No. 15

PARTI ES, UNI ONS, AND ACTI VATI ON STRATEGI ES:

THE CONTEXT- DEPENDENT POLI TI CS OF ACTI VE LABOR MARKET POLI CY SPENDI NG

August 2013

MARKUS TEPE

PI ETER VANHUYSSE 


\section{Parties, Unions, and Activation Strategies: The Context-Dependent Politics of Active Labor Market Policy Spending}

CELSI Discussion Paper No. 15

August 2013

Markus Tepe

University of ol denburg

\section{Pieter Vanhuysse}

European Centre for Social Welfare Policy \& Research

The Central European Labour Studies Institute (CELSI) takes no institutional policy positions. Any opinions or policy positions contained in this Discussion paper are those of the author(s), and not those of the Institute.

The Central European Labour Studies Institute (CELSI) is a non-profit research institute based in Bratislava, Slovakia. It fosters multidisciplinary research about the functioning of labour markets and institutions, work and organizations, business and society, and ethnicity and migration in the economic, social, and political life of modern societies.

CELSI Discussion paper series is a fIagship of CELSI's academic endeavors. Its objective is the dissemination of fresh state-of-the-art knowledge, cross. fertilization of knowledge and ideas, and promotion of interdisciplinary dialogue about l abour markets or broader l abour issues in Central and Eastern Europe. Contributions from all social science disciplines, including but not li mited to economics, sociology, political science, public polic social anthropology, human geography, demography, law and social psychology, are welcome. The papers are downloadable from http:// www. celsi.sk. The copyright stays with the authors.

Central European Labour Studies Institute (CELSI)

Zvolenská 29
821 09 Bratislava
Slovak Republic

Tel/Fax: $+421-2-20735767$
E-mail: info@celsi.sk

We b: www.celsi.sk 
CELSI Discussion Paper No. 15

August 2013

\section{ABSTRACT \\ Parties, Unions, and Activation Strategies: The Context-Dependent Politics of Active Labor Market Policy Spending*}

This article explores the diverging roles of leftwing parties and trade unions in determining active labor market program (ALMP) spending. We argue that unions today increasingly take into account the distinct re-employability worries of their members. Rather than as a labor market outsider program, unions now consider ALMPs, especially those sub-programs most directly useful to their members, as their second-best or first-best feasible priority. Specifically, in countries where high job protection levels (the first-best goal) have not been achieved, more powerful unions will promote ALMP spending as an alternative way to offer their members some measure of labor market security. We test these arguments on a sample of 20 OECD countries between 1986 and 2005. Using a new measure of leftness, we find that leftwing party power has no effect on ALMP spending generally and a negative effect on job creation programs. By contrast, larger and more strike-prone unions are associated with higher ALMP spending overall, and specifically on those programs most benefiting their members: employment assistance and labor market training. Moreover, union strategies are context-dependent. More powerful unions push for more activation spending especially in labor markets where jobs are not yet well protected.

Keywords: activation paradigm, leftwing parties, union strategies, re-employment worries, insiders and outsiders, labor market policy, power resources

JEL Classification:

\section{Corresponding Author:}

Pieter Vanhuyse

European Centre for Social Welfare Policy \& Research

Berggasse 17, A-1090 Vienna, Austria

E-mai I: vanhuysse@euro.centre.org 


\section{INTRODUCTION}

Whereas cutbacks in the size and generosity of social policies have largely dominated the 'new politics' of welfare since the 1980s, skill training and active labor market policies (henceforth ALMPs) have increasingly acquired a central role in the rhetoric and policy tools of most OECD governments. ${ }^{1}$ These developments have been accompanied by a renewed interest by comparative political scientists in the underlying partisan drivers of ALMP spending. In particular, Rueda $(2005,2006,2007)$ argues that re-election seeking social-democratic parties today have relatively little interest in promoting ALMPs, as they increasingly see their electoral core as labor market insiders, not the outsiders that allegedly most benefit from ALMP programs. But the approaches of trade unions towards ALMPs have been studied less extensively. This study investigates the roles of both leftwing governments and unions in ALMP spending, and how these roles vary across institutional contexts.

Since there is still mixed evidence on the Rueda hypothesis, we provide an review of the existing empirical findings and seek to reproduce these findings using a refined measure for leftwing governments taking into account the cabinet power and the ideological position of incumbent parties. Second, rather than considering unions as narrowly focused employment protection promotors, we argue that unions now need to be responsive towards the increasing re-employability worries of their current and future members. Unions today may therefore consider ALMPs as a second-best priority program. Where high levels of employment protection legislation (henceforth EPL) have not been achieved (the first-best goal), more powerful unions can be expected to push for 
activation spending as an alternative way to offer their members some measure of labor market security.

We explore these considerations on a sample of 20 OECD countries from 19862005. Our main findings can be condensed in three statements. In contrast to old power resources theories (e.g. Korpi 1983), but in line with recent studies in the wake of Rueda $(2005,2005,2007)$, we find that governments with a stronger leftist orientation do not increase ALMP spending and in fact significantly reduce job creation programs. Second, we point out that union members worry more than non-members about their reemployability but less than non-members about their job security. We then show that greater union power in the form of higher density rates and higher strike activity tends to increase overall ALMP spending, and specifically those sub-dimensions that most help union members: employment assistance and, especially, labor market training. Lastly, whereas the effect of leftwing values in government on ALMP spending is not influenced by the degree of EPL, both higher union density rates and higher strike rates more strongly boost ALMP spending in labor market contexts with low levels of EPL. Contradicting blanket portrayals of unions as narrow interest groups single-mindedly pushing for job protection, union strategies towards ALMPs have adapted to the new politics of welfare retrenchment and austerity by taking into account the re-employability worries of their members and by pragmatically adjusting their policy priorities according to the institutional contexts in which they operate. 


\section{PRIOR EVIDENCE: PARTIES, UNIONS AND ALMP SPENDING}

In the wake of Rueda's $(2005,2006,2007)$ seminal contributions, a growing literature emerged that explores the effect of partisanship on ALMP spending. Table 1 aims to summarize the main findings of eleven key studies published since then. Cumulatively, these studies provide mixed and inconclusive evidence on the effect of partisan power on ALMP. The majority of studies find that the ideological composition of government has no statistically significant effect on ALMP spending (Rueda 2005; Franzese \& Hays 2006; Armingeon 2007; Gaston \& Rajaguru 2008; Vlandas 2011). Rueda (2007: 92, 95) finds that lagged levels of leftwing power have no significant effect on ALMP spending and increases in leftwing power a significant and negative effect. But Iversen and Stephens (2008) and Huo et al. (2008) report significant positive effects and Van Vliet and Koster (2011) report that rightwing governments decrease ALMP spending.

Table 1

Less attention has thus far been paid to the role of trade unions in ALMP spending, even though some of these findings stand in sharp contrast to the predictions of economic insider-outsider models (Lindbeck \& Snower 1988; 2001; Saint-Paul 2000). Of the four studies that utilized union density as a measure of union strength (Rueda 2005; Franzese \& Hays 2006; Rueda 2007; Vlandas 2011), two report a positive significant effect on ALMP spending (Rueda 2005; Vlandas 2011). Iversen \& Stephens (2008) explored the effect of strike activity on ALMP spending and find a negative but non-significant relationship. 
A third political variable that has gained scholarly interest is welfare regime type. Armingeon (2007) and Tepe and Vanhuysse (2010) report that countries belonging to the Scandinavian welfare regime spend significantly more on ALMPs. Robust findings have been reported on the effect of macro-economic control measures on ALMP spending. Three exceptions notwithstanding (Franzese \& Hays 2006; Van Vliet \& Koster 2011; Vis 2011), unemployment is generally associated with increases in ALMP spending. Even more robust evidence has been obtained with respect to government deficits: all studies that take this variable into account report a negative relationship with ALMP spending.

The literature review also reveals various issues regarding the comparability of prior evidence. First, even though the eleven studies explore different time periods and country samples the large majority relies, like Rueda (2005, 2006, 2007), on a crosssectional time-series (CSTS) regression setting to estimate the impact of political determinants on ALMP spending. Second, whereas the appropriate conceptualization of the dependent variable in comparative political research has received much attention in the comparative political analysis of social expenditure, Table 1 shows that there are at least three alternative conceptualizations of ALMP spending. Third, even though almost every study presented in Table 2 relied on CSTS regression, the authors have chosen very different approach to account for the panel structure of their data. We will try to address some of the methodological issues raised in this review of prior evidence in Section 4. The next step of the analysis, however, is to make sense of the mixed evidence on the role of left parties and trade unions towards ALMP spending. 


\section{THEORETICAL BACKGROUND AND HYPOTHESES}

To understand why leftwing parties and unions have developed divergent strategies towards ALMP, we begin by looking at the long-term fortunes of these actors. Figure 1 depicts trends in the share of workers in the industrial sector relative to those in the agrarian and service sector, the share of cabinet seats held by leftwing parties and union density in the last four decades as averages for 20 OECD countries. Mainstream leftwing parties had a mixed political fate, as they suffered losses of power after the end of the welfare state's 'Trente Glorieuses' by the mid-1970s, but returned to power towards the second part of the 1990s, often under 'new left' guises. To do so, left parties in the 'postgolden era' of the welfare state have had to pursue often very different electoral and policy strategies than in previous decades (on which more below). By contrast, Figure 1 shows that union density reached its peak in the 1980s, after which there has been a constant and near-universal decline, parallel to the decline in the industrial labor share. ${ }^{2}$ To this loss of external clout was added a loss of clout inside the old labour movement in some countries especially in the Anglo-Saxon world, as unions have had their voting power on leftwing parties' policy direction reduced considerably (most obviously in part of the Anglo/American regime group).

Figure 1 


\subsection{Leftwing parties and ALMPs: the new politics of disinvestment?}

'Old' power resources theories in the tradition of Korpi (1983) hold that leftwing party power in government are key in the early installation and subsequent expansion of ALMPs in an effort to increase employment levels and to insure their rank and file originally industrial workers - against job losses, to retrain and reskill them and, more generally, to de-commodify workers by making them less dependent on pure market forces (e.g. Esping-Andersen 1990; review in Jensen 2012). Other political science approaches less directly influenced by power resources theory similarly posit proexpansion attitudes of leftwing parties towards ALMPs (Janoski 1994; Boix 1998). In an era of globalization in which the degrees of freedom of governments to intervene in the economy through tax-and-spend approaches seem to be reduced by the likelihood of capital flight, ALMPs have acquired further importance, as they remain a key policy tool clearly at the disposal of governments. More than non-denominational rightwing parties or Christian-democratic parties, leftwing parties may be more inclined to intervene directly to boost the supply side of labor markets by upgrading skills, job rates, and employability (Boix 1998; Iversen \& Stephens 2008). The traditional power resources hypothesis on partisanship would therefore still posit that leftwing party power will drive up ALMP spending.

This view has been challenged by Rueda (2005, 2006, 2007), who argues that leftwing parties have adopted a different approach to ALMPs especially in recent decades, with the rise of the service sector economy and of dual labor markets. Like economic insider-outsider theories (Lindbeck \& Snower 1988, 2001; Saint-Paul 2000), 
Rueda points out that labor is not a homogenous block, but he adds an explicitly political dimension by unambiguously taking as his starting point the thesis that 'the electoral goals of social democratic parties are sometimes best served by pursuing policies that benefit insiders while ignoring the interests of outsiders' (Rueda 2007:12). Leftwing parties, in this account, view only traditional labor market 'insiders' (essentially low-tomiddle-income wage earning workers with highly protected jobs) as their core voting base, which they need to favor predominantly with policies that protect employment. Rueda (2007) therefore posits a straightforward choice of leftwing parties in favor of insiders, not least because the latter tend to share relatively much more homogenous interests and to be organized in unions. By contrast, leftwing parties see increasingly less electoral need to spend on ALMPs that tend to favor labor market 'outsiders' (primarily the unemployed and atypical workers such as part-time, flexi-time and temporary workers) - they might even want to reduce ALMP spending in times of macro-fiscal austerity. $^{3}$

In addition, to win elections by capturing middle-class voters beyond the shrinking base of industrial workers, leftwing parties in recent decades have shifted their ideological positions towards more centrist welfare positions and to emphasize different (often explicitly women-friendly) social programs such as human capital investment, family policies and childcare (e.g. Bonoli \& Reber 2010; Jensen 2012; Esping-Andersen 2009). For instance, election manifestos, party and policy programs and parliamentary debates show that on key social policy decisions, continental European leftwing parties have increasingly converged towards mainstream Christian-democratic parties (SeeleibKaiser et al. 2009). Promoting family and childcare policies, for instance, made leftwing 
parties more attractive for (and distinct to) female voters at a time when their traditional electoral base was rapidly eroding because of deindustrialization and when women increasingly expected state support for combining employment with motherhood (Bonoli \& Reber 2010; Esping-Andersen 2009). Such strategies have become increasingly viable electorally as the democratization of higher education access and the expansion of service sector employment have created simultaneously a wider and more heterogeneous base of middle-class voters (Häusermann \& Schwander 2009).

In light of both sets of arguments, a 'new left' partisan hypothesis therefore posits that leftwing values power in government (which we take to include both the ideological position of the government on an ideological left-right scale and the share of seats in the cabinet held by leftwing parties ${ }^{4}$ ) will not, or will negatively, affect activation spending:

H1, Left party disinvestment thesis: Leftwing values power in government has no effect (weak version) or a negative effect (strong version) on ALMP spending

\subsection{Unions and ALMPs: context-dependent advocacy, driven by members' worries?}

Whereas Rueda $(2005,2006,2007)$ provides new theoretical perspectives on the evolving position of leftwing parties, no coherent political-theoretical framework has been developed to understand unions' approaches towards ALMPs in times of continued loss of members (Figure 1). Yet, especially when it comes to social policies, these two sets of actors do not necessarily pursue identical goals, nor do they have identical constituencies (Jensen 2012). The organizational success of leftwing parties depends primarily on their ability to win office by maximizing votes, increasingly from women and middle-class 
voters. The success of unions, by contrast, depends primarily on their ability to gain or consolidate membership through their effectiveness in representing the labor market interests of their members.

To be sure, women-friendly policies and higher education democratization have also been promoted at times by more progressive unions in an effort to assist their women members. And many outsider-type workers in low EPL-labor markets with large proportions of part time and casual workers tend to be women and are not necessarily middle-class voters. ${ }^{5}$ But the fact remains that even today the membership core of unions still lies predominantly with industrial workers (Ebbinghaus et al. 2011; Palier \& Thelen 2010). Demand-side gender divergence can further explain party-union policy divergence. Female voting turnout rates do not significantly differ from male rates, which further makes women-friendly party platforms electorally viable. But due to gendertypical employment patterns, women do record lower, often much lower, union membership rates than men in almost all advanced economies outside Nordic and Baltic Europe. ${ }^{6}$ Unions may therefore be less able than leftwing parties to shift towards 'modernizing' social policy positions (Upchurch et al. 2009). There is a growing evidence of such party-union divergence, both as regards other social policy programs (Jensen 2012; Häusermann 2010) and as regards general social spending (Kwon \& Pontusson 2010). ${ }^{7}$ Even in the present times of general union decline, labor market policies remain one of core areas for unions, in terms of both policy influence (Davidsson \& Emmenegger 2012) and goal prioritization (Jensen 2012). This is undoubtedly because labor market policies reflect the key concerns of the unions' rank and file, who tend to be 
labor market insiders. But how do unions approach ALMPs, which have been commonly viewed as benefiting outsiders?

Standard political economy accounts assume that unions pursue the interests of insiders - primarily wages and job protection - often with little regard to society or even workers at large (Lindbeck \& Snower 1988; 2001; Saint-Paul 2000; more refined predictions from similar assumptions are Olson 1981; Calmfors \& Driffill 1988). Rueda (2007: 28) similarly argues that unions, 'in a more significant way than social democratic parties (since upscale groups are of no importance to unions that depend primarily on insiders), have strong incentives to defend the interests of insiders' (emphasis added). Such a view would posit that greater union power following from a larger membership or stronger strike capacity will lead unions to push for insider protection exclusively (such as EPL), even at the expense of alleged outsider programs (such as ALMPs).

However, in the wake of liberalized labor markets (even in coordinated market economies), growing international competition and increasingly punctuated working careers, the interests of union members today are not the same as during past times of welfare state expansion. To be sure, members are as likely as ever to demand continued job security protection from their leadership - indeed even labor market outsiders desire such protection ideally (Emmenegger 2009). But in addition, especially since union members are likely to be more exposed to international competition and to feel threatened by further industrial decline, union leaders today also need to ensure workers' reemployability chances. Citizens generally see labor market policies as more important for providing them with a sense of employment security in crisis times than job protection policies such as EPL (Chung and van Oorschot 2011). Already by 1997, workers across 
15 OECD countries perceived ALMPs as boosting their re-employment chances: general levels of ALMP spending had no effect on workers' job insecurity ('job worries') but significantly reduced workers' reemployment insecurity in case of job loss ('reemployability worries') (Anderson \& Pontusson 2007). Interestingly, union membership itself was simultaneously associated with lower perceived job insecurity and with higher subjective re-employability insecurity (Anderson \& Pontusson 2007, 220-221). In Figure 2, we have computed updated evidence from almost one decade later - the ISSP 2005/2006 wave - on the same two variables: job worries and re-employability worries.

Figure 2

On average, union members wide across the OECD are significantly less worried than non-members about the security of their current job. This is consistently the case across three different conceptions of 'job worries'. But when it comes to their re-employability in the event of job loss, union members are actually significantly more worried than nonmembers. In fact, members are more worried nearly everywhere - in sixteen out of seventeen OECD countries (not shown). Especially in times of falling union membership, these re-employability worries are likely to feed back to union leaders and be heard by them, leading them to use their political clout to push for higher ALMP spending for reasons of organizational self-interest. Admittedly, unions, let alone national union movements, are not unitary actors. Environments with many smaller unions potentially produce different strategic interactions and policy outcomes than environments with few medium-sized or still fewer large unions (Olson 1981; Calmfors \& Driffill 1988; Brandl 
\& Traxler 2010; Traxler \& Brandl 2010). Moreover, the leaders and members of unions are subject to similar principal-agent problems as characterize the relationship between voters and politicians, or employers and employees (Golden 1992; Vanhuysse 2006; Vanhuysse \& Sulitzeanu-Kenan 2009). But we nevertheless assume that union leaders in hard times will generally have strong incentives to promote the distinct and clearly expressed interests of their mainstream members. For the same reason, we expect union leaders to seek to increase ALMP spending particularly on those sub-dimensions that are most likely to help their own members. ${ }^{8}$ Thus they are likely to be relatively less interested in promoting job creation programs, which mainly benefits (non-unionized) labor market outsiders. But by the same token, union leaders can be expected to use their political power to strongly promote employment assistance and, especially, labor market training, which is the ALMP sub-dimension that is most likely to benefit (potential) union members. This leads us to hypothesize:

H2, Self-interested advocacy thesis: Larger and more strike-prone trade unions have a positive effect on ALMP spending generally, and on employment assistance and labor market training specifically.

But in addition, the ALMP strategies of unions are likely to be context-dependent. In particular, the labor market laws and institutions under which unions operate can be expected to condition their ALMP stances. Given the remaining importance of job security for union members, employment protection legislation is likely to be a key variable in this respect. ${ }^{9}$ At the micro level, high levels of employment protection levels can be assumed to be a dominant social policy interest of labor market insiders, and to 
constitute their prime demand towards the parties and unions representing them. Indeed, greater levels of subjective job insecurity tend to be systematically correlated with less member satisfaction with unions, less identification with unions and a stronger desire to leave unions (Näswall et al. 2004). At the macro level, high contemporary EPL levels can be viewed a major acquis social and a proxy of past successes of the traditional labor movement (old leftwing parties and trade unions). Levels of employment protection differ according to the larger macro-political economy models countries belong, with coordinated market economies recording higher levels than liberal market economies (Iversen 2005; Palier \& Thelen 2010). But once implemented, these levels are remarkably sticky at least for workers on regular contracts, indicating small and incremental rather than radical changes in past decades. Hence, contemporary EPL levels can be viewed not only the result of contemporary expansion drives for higher standards in protecting labor market insiders but also as the institutional context in which unions operate.

On the part of union members, support for ALMPs appears to decrease where unemployment (and thus job competition) is high but to increase where job protection is low (Nelson 2009). On the part of union leaders, the awareness of their members' increasing re-employability worries shown in Figure 2 can similarly be expected to be context-dependent. It is likely to be especially salient in low-EPL labor markets, given that industrial job loss is more likely in these more liberalized higher-turnover and shorter-tenure contexts (Iversen 2005). Hence, we expect union leaders to be especially eager to push for policies that boost workers' reemployment chances and help to countervail re-employability worries in such low-EPL contexts. ${ }^{10}$ This leads us to hypothesize: 
H3, Context-dependent advocacy thesis: Lower levels of EPL will be associated with a stronger positive effect of union density and of strike rates on ALMP spending

In other words, where and when high EPL has already been achieved (the first-order goal), unions are expected to focus their political clout mainly on defending and consolidating these past successes. But when and where high EPL levels have historically not been achieved for a variety of political economy reasons, more powerful unions can be expected to more strongly promote ALMP spending (the second-best, or first-best feasible goal), as an alternative way to offer their membership some measure desired labor market security, in the form of state help towards their potential re-employability.

\section{DATA AND METHOD}

Focusing on cross-sectional differences in the level of ALMP spending we divide the OECD sample into four welfare regime types (on variables, see Appendix table 1). ${ }^{11}$ In line with Esping-Andersen (1990) and others, we expect both the ingrained institutional logics and the historical timing of active social spending to lead Nordic welfare regimes to spend significantly more, and Southern European regimes to be significantly less on ALMPs. The political power of leftwing parties is almost invariably operationalized as the percentage of cabinet seats held by leftwing parties (see the critical review in Jensen 2012). This approach increasingly ignores the ideological position of contemporary leftwing parties. Since modernized and distinctly pro-market social democratic parties won office under various labels in the 1990s in some countries (e.g. the 'Neue Mitte' 
SPD in Germany, 'New Labor' in the UK) but not in others (e.g. the PS in France and in francophone Belgium, the SPÖ in Austria), there is little doubt that leftwing parties in government can differ significantly in their ideological beliefs. The Comparative Manifesto Project (Budge et al. 2001; Klingemann et al. 2006) has coded government declarations in order to describe the ideological (rather than nominal) positions of governments with a left-to-right measure ranging from -100 (extreme left) to +100 (extreme right). This clearly shows that leftwing governments in Britain have clearly become more centrist over time. Upon their launch in 1976, 1997 and 2001, the Callaghan, Blair-I, and Blair-II governments had left-to-right values of respectively -27.5, +8.07 and +5.58 . Similarly Germany's Schmidt government in 1976 was significantly leftwing (-18.44), whereas the next left-led government, Schröder-I in 1998, was essentially centrist (-2.11). We use the left-to-right measure provided by the Comparative Manifesto Project to account for changes in the leftwing ideology of parties in government. ${ }^{12}$

However, a pure measure of the ideological position of a government on the rightleft scale would ignore the vote share of left parties in the cabinet, and thereby the share of "leftness" that can be accounted to social democratic parties in government. Hence, we constructed a measure of leftwing values power in government, which takes into account both the ideological position of the government on the left right scale and the share of seats in the cabinet held by leftwing parties.

(1) Leftwing values power $=\operatorname{sqrt}($ Left ideology $\mathrm{x}$ Left cabinet seats) 
Before the original Comparative Manifesto Project left-to-right variable entered (1), it has been subject to the following transformations. First, the variable has been reversed so that -100 stands for extreme right and +100 for extreme left-leaning governments. Second, we have rescaled the new variables within each country so that the lowest value on the scale gets the value 1 (extreme right). Hence, theoretically the highest value on the reversed and rescaled variable measuring governments' ideological position is 201 (extreme left). Empirically the country-specific right-to-left measure for governments' ideological position ranges from 1 (extreme right) to 64.4 (extreme left). Third, we have chosen to measure the ideological position of governments relative to the most right-leaning government in each country during the observation period as Comparative Manifesto Database measures are most valuable in capturing positional changes within rather than between countries.

Left cabinet seats are measured as a share of total seats and range from 0 to 100 . We took the square root of the product of the two measures since we assume that an increase in left values power matters more in governments where the leftwing coalition partners have little influence than in governments which is already dominated by the leftwing partie(s). The advantage of this measure is that it takes into account changes in the ideological position of left governments over time.

To account for the political strength of unions in determining ALMP spending, we distinguish two dimensions of the political clout of unions, namely the size and the "aggressiveness" of unions. The size and potential impact of unions is measured as union density, in line with prior studies (Table 1), defined as net union membership as a proportion of wage and salary earners in employment (Armingeon et al. 2011). Unions 
can have much political influence through strikes in low-density countries (e.g. France) or alternatively may be socially non-disruptive in high-density countries (e.g. Nordic Europe). Strike aggressiveness is therefore a politically distinct dimension of trade unionism. It is measured by the logarithm of the index of strike activity. The strike activity index is defined as the number of working days lost divided by the number of civilian employees multiplied by 1000 (Armingeon et al. 2011).

In order to account for the context effect of employment protection legislation we use the measure provided by the OECD, which refers to all types of employment protection measures, whether grounded primarily in legislation, court rulings, collectively bargained conditions of employment or customary practice. ${ }^{13}$ The OECD index of EPL is classified in three main areas: employment protection of regular workers, specific requirements for collective dismissals; and employment protection of temporary workers. Employment protection legislation is measured via the unweighted average of the OECD's version 1 sub-indicator for regular contracts (EPR_v1) and temporary contracts (EPT_v1).

Each model includes a set of four control variables, which aim to capture longterm macro-economic developments. The selection of these control measure is based on the prior evidence summarized in Table 1. General macro-economic developments are captured with the GDP growth rate. The fiscal resources of governments are measured in terms of government deficits as a share of GDP. In general we expect that higher deficits will lead governments to cut first and foremost smaller programs with high levels of spending discretion such as ALMPs. The opposite effect should be observed with respect to the unemployment rate, as higher levels of unemployment should lead governments to 
react by spending more on all forms of ALMP, especially since the 1990s when ALMPs became more fashionable and better promoted also at EU levels. In fact, unemployment should be the most important time-varying determinant for ALMP spending. Here, the more challenging question is whether unemployment has the same effect on different types of AMLP spending. Finally, international economic integration is measured in terms of trade openness. Appendix Table 1 presents the definition and source of the variables employed in the regression analysis. Appendix Table 2 shows the summary statistics of the z-standardized variables.

\subsection{Estimation strategy}

Since we are interested in structural changes and long-term contextual effects of labor market institutions on ALMP spending, rather than annual fluctuations, we have grouped annual observations into five-year averages. The variables for each country are calculated as averages of, respectively, the periods 1986-1990, 1991-1995, 1996-2000 and 20012005. It has been argued that the 1990s mark a significant increase in the centrality of ALMPs as a policy tool (e.g. Bonoli 2010; Weishaupt 2011). The breakdown of time periods is not only a way for taking into account the fact that electoral and social changes often need time to materialize into public policy efforts but also allows us to explore the existence of potential "sea-changes" in the size of ALMP spending. The averaging procedure makes a balanced sample of 80 observations $(\mathrm{T}=4, \mathrm{~N}=20) .{ }^{14}$ Given the dataset's panel structure, a key question is whether the country effects should be treated as random or fixed (see Table 1). The random-effect estimator is heavily influenced by cross-sectional variance and depends on the assumption that unobserved heterogeneity is 
mean independent of the causal variable (Halaby 2004: 511). This assumption would be defensible under randomized assignment but less so in a sample consisting of 20 OECD countries, where each unit is having a distinct set of social security institutions. The fixed-effects estimator, which exploits within-unit variation as a means of purging unit heterogeneity, offers to dispense the random-effects assumption and still obtains unbiased and consistent estimates when unit effects are arbitrarily correlated with explanatory variables (Halaby 2004: 516). To separate within-unit and between-unit effects, we apply two different models: one focusing on change over time within countries (FE), and one focusing on variance over time between countries $(\mathrm{BE})$, as mixing up within-unit and between-unit effects would hamper a clear interpretation of our estimated coefficients (Breusch et al. 2011). In order to obtain easily interpretable estimation coefficients all metric variables have been $\mathrm{z}$-transferred $(\operatorname{mean}=0, \mathrm{sd}=1)$. To compare the model fit for different specifications we report the adjusted R-square, the AIC and BIC. ${ }^{15}$

\section{RESULTS}

\subsection{Descriptive analysis}

In line with prior research, Table 2 shows that, on all three measures of ALMP spending, Scandinavian countries have spent most, followed by continental European and AngloAmerican countries. Southern European countries have devoted the fewest resources to ALMPs measured in terms of spending per GDP and spending per unemployed, followed by Anglo-Saxon countries. The strength of leftwing parties is represented in the fourth and fifth column. Measured by cabinet seats, since 1985 leftwing parties have been strong in the Scandinavian countries (55 percent of seats) and weak in the Anglo- 
American countries (27 percent), whereas their average seat share in Continental and in Southern European countries was almost identical (36-38 percent).

If we take into account the ideological positions of governments we observe a number of interesting deviations that point out the importance of an adequate operationalization of theoretical constructs. Leftwing cabinet power and leftwing ideology are clearly two different things. There are a number of cases, such as Portugal, where over the twenty-year period considered successive governments had a low share of left party seats (26 percent of seats) despite holding rather left-leaning ideological positions (13 on the -100 to +100 scale), or vice versa, as in the case of Spain and Sweden (respectively 60 and 85 percent of government seats, but essentially centrist). Intra-regime variance is large as well, especially within the Anglo-Saxon regime, where there is more variance in institutional (e.g. such PR versus majoritarian) regimes. For instance, New Zealand and the UK had widely diverging degrees of government leftness (respectively +17 and -19) despite (roughly) similar levels of leftwing seats. By contrast, the USA experienced equally rightwing governments $(-23.5)$ as the UK, despite having zero (as opposed to 43) percent of left cabinet seats, while Canada experienced much less rightwing governments (-6.2) than the USA with the same share (zero) of leftwing cabinet seats. In sum, differentiating between the cabinet power of leftwing parties and the actual left-ideological positions of governments can provide richly differentiated information.

Table 2 
A similar conclusion can be drawn from the cross-national comparison of the two measures for union clout. Strike activity and union density clearly capture qualitative differences in the type of union power. Moderate levels of union density are paired with low levels of strike activity in Continental Europe but with high levels of strikes in the Anglo-Saxon world (especially in Canada). The Nordic regime tends to combine moderate to high strike activity with high union density. The Southern regime in turn combines the lowest union density levels with the highest strike activity levels, especially in Spain. The last column of Table 2 shows that EPL is particularly strong in the Southern countries, followed by the Nordic and Continental European countries and, at a distance, the Anglo-Saxon countries.

\subsection{Regression analysis}

Table 3 presents findings from the analyses of continuous long-term change in total ALMP spending measured as a share of GDP. Model 1 focuses on overall cross-national variance. For this purpose we rely on the between-effects specification (employing country averages), which is most suitable to account for time-invariant independent variables such as welfare regime affiliation, whereby the liberal regime served as the reference category. Cross-sectionally, countries with larger deficits spend significantly less on ALMPs, whereas more open countries, countries with higher unemployment levels, and Nordic welfare countries spend significantly more. The regime type findings are of course in line with much prior evidence (e.g. Bonoli 2010; Iversen \& Stephens 2008; Tepe \& Vanhuysse 2010). 
Table 3

Models 2 to 7 in Table 3 focus on change in ALMP spending over time within countries, using a country fixed-effects specification with robust standards errors. The temporal dynamics are accounted for by period dummies, which, rather than presuming a linear time trend, allow one to check for the possibility that ALMP spending in one period might have been larger than in the first period (reference category) while in another period it might have been smaller. We find that the time variable coefficient is positive and typically significant in all six models. Model 7 in particular, indicates not just that ALMP spending was significantly higher in the early 1990s than in the late 1980s, but that the effect size subsequently doubles between the early and the late 1990s, staying at higher levels into the early 2000s. This supports the thesis that the mid-to-late 1990 s were a watershed regarding the centrality of ALMPs as a policy tool. In the case of EU member states, this may be explained in part by the greater emphasis given to these programs from the second half of the 1990s, notably as a result of the 1994 Essen summit, the European Employment Strategy and the Luxemburg Employment Summit (both in 1997), and the 2000 Lisbon Treaty. ${ }^{16}$ Among our economic control variables, neither GDP growth rates nor trade openness or unemployment levels significantly affect ALMP spending within countries. When the temporal dynamics are accounted for by a linear time trend (rather than period dummies), unemployment rates systematically increase ALMP spending. This indicates that ALMP spending is not generally cut back in hard times whenever higher unemployment levels automatically drive up passive labor market spending. On the other hand, higher deficits are negatively associated with AMLP 
spending in Table 3. This might be because this relatively small and relatively new social program suffers from a last-in-first-out effect at times when macro-fiscal savings are needed or, conversely, because lower ALMP spending leads to higher inactivity and welfare dependency rates and hence to larger budget deficits. The latter interpretation is consistent with the original rationale of ALMPs in Nordic countries, as espoused also at the EU level today: ALMPs help to increase activity rates and thus to reduce unemployment levels and budget deficits.

Turning to our political variables, Models 2 to 7 investigate the effects of leftwing values power and union power. The left party cabinet share variable most often used in research on partisanship shows no significant effect (Model 2), but the Comparative Manifesto Database's ideology variable indicates that more leftwing governments significantly reduce ALMP spending (Model 3). Our own combined variable, 'left values power,' also indicates a negative relationship (Models 4 and 7). Though both estimates narrowly fail to reach conventional statistical significance levels (Model 6, p-values 0.102) the observed relationship lends some measure of support for (a weak version of) the left party disinvestment thesis (H1). Interestingly both measures of union clout are systematically associated with significantly higher levels of ALMP spending (Models 5, 6 7). Even after controlling for macro-economic and partisan-political variables, both larger unions and more aggressive unions appear to push for higher spending for labor market outsiders, corroborating the self-interested union advocacy thesis (H2).

How do these findings change if we use ALMP spending per unemployed and ALMP spending as a share of passive labor market policy spending as the dependent variable (Appendix Table 3)? Whereas ALMP spending per GDP measures the absolute 
size of these programs, ALMP spending per unemployed seeks to take into account relative program generosity and ALMP spending as a share of passive labor market program spending (PLMP) indicates the tradeoff between these two programs. Regarding our main political variables, we find that the effect of strike activity (but not union density) on ALMP spending both per unemployed person and as a share of PLMP spending remains positive and statistically significant (Appendix Table 3). ${ }^{17}$ In other words, strike activity is positively associated with all three measures of ALMP spending.

Table 4

Table 4 replicates the political Models 4, 5 and 6 from Table 4, but focusing on the three sub-dimensions of ALMP spending suggested by Bonoli (2010). Compared to Table 3, the main differences here are that leftwing values power negatively affects job creation program spending specifically. As this is the ALMP subprogram that most directly benefits outsiders, this finding provides support for a stronger version of the left party disinvestment thesis (H1). The very opposite is true for union power. The coefficients for union density rates and strike rates show that stronger unions push for higher spending on those ALMP sub-programs that most directly help their own members: employment assistance and, especially, job training. Together with the absence of a similar effect on job creation programs, this provides further and more specific support for the selfinterested advocacy thesis (H2). Powerful unions may appear to act (or pose) as ALMP promoters generally, but they tend to make sure to benefit their own rank-and-file first and foremost. 


\subsection{Context-dependent union strategies}

While we have found above that both larger unions and more aggressive unions appear to push for higher ALMP spending, we also hypothesize that union (but not party) strategies towards such spending depend on whether or not labor market insiders are already highly protected in their jobs (H3). To explore this argument we stepwise introduce three multiplicative interaction terms into our sets of three regression models (interacting EPL with left values power, union density, and strike activity). With three political variables of theoretical interest and three different conceptualizations of the dependent variables we get nine conditional effect models (Appendix Table 5). Even though EPL is a timevarying measure, it changes only very gradually within countries over time. This might cause multicollinearity. To explore this potential issue in further detail we checked changes in the VIF, which reports unproblematic values (min. 2.15) and we test the exclusion of the full set of country dummies using a series of Wald Tests. Test results indicate that the full set of country dummies needed to be kept in the conditional effect models.

Figure 3 represents the conditional effect of EPL on the effect of union density on our three measures of ALMP spending when EPL is respectively at its minimum level (equivalent to 0.21, the USA value throughout 1986-2005) and at its maximum level (4.15, the Portugal value in 1985-1988). To interpret the conditional effect of EPL on the effect of the three political variables we use conditional effect plots as suggested by Franzese \& Kam (2007). Each of the resulting nine plots shows the effect of the political variable on the predicted level of ALMP spending when the political variables ranges from its minimum to its maximum value, in the context of maximum EPL (grey dots) and 
minimum EPL (black dots). Each point estimate comes with a $90 \%$ confidence interval, whereas overlapping intervals indicating insignificant interaction effects. ${ }^{18}$

Figure 3

The first column in Figure 3 shows the predicted effect of left values power on the three measures of ALMP spending. In all three cases the high-EPL and low-EPL lines are almost identical and the $90 \%$ confidence intervals are almost perfectly overlapping. Hence, there is no evidence that the effect of left values power on ALMP spending is in any way conditioned by EPL. The second column shows the predicted effect of union density on the three measures of ALMP spending in high- and low-EPL contexts. Here a scissor-shaped pattern emerges. Concerning ALMP spending per GDP and per unemployed, union density leads to strong increases in both measures where EPL is low. Where EPL is high, increases in union density still increase ALMP spending, but the positive effect is rather moderate. Taking into account the $90 \%$ confidence intervals, however, reveals that none of the three conditional effects is statistically significant. In contexts with very high levels of EPL (as in contemporary continental and Southern Europe), higher union density has a negative effect on ALMP spending. However, where EPL is very low (as in Anglo-Saxon liberal market economies), higher union density leads to large increases in the predicted level of ALMP spending.

Labor conflict is similarly likely to be a matter of strategic union choice as embedded in specific economic and institutional contexts (Brandl and Traxler 2010). Not surprisingly therefore, a similar scissor-shaped pattern is evident also when investigating 
how EPL mediates the effect of strike rates on ALMP spending. Now the conditional effect reaches conventional levels of statistical significance in the cases of ALMP spending per GDP and per unemployed. More assertive unions have a weak and negative effect on total ALMP spending as a share of GDP in highly protected labor markets, but have a stronger and positive effect on ALMP spending on weakly protected labor markets.

These findings provide some evidence for the context-dependent advocacy thesis (H3). Unions with more political clout might more strongly push for ALMP spending mainly when and where regular workers are not yet well protected. This may be because in contexts where high EPL levels have never become a key part of the larger macropolitical economy model, ALMPs have become the first-best feasible union priority, as they offer workers support for reskilling and retraining and can simultaneously be presented as a clearly market-conform or market-strengthening policy. In other words, unions today appear to consider ALMPs as a second-best goal, EPL being their first priority. ${ }^{19}$

\section{CONCLUSIONS}

This study has explored the role of leftwing governments and trade unions in determining ALMP spending and has proposed an explanation for why leftwing governments and trade unions today appear to pursue divergent strategies in this regard. Our findings can be condensed into three statements. First, left values power does not tend to increase ALMP spending (corroborating H1, weak version), and actually decreases spending on job creation programs, which are most likely to benefit outsiders (H1, strong version). 
Both findings are consistent with Rueda's $(2005,2006,2007)$ pioneering thesis that leftwing parties care relatively little for outsider spending. Second, in line with the idea that unions' ALMP strategies increasingly need to take into account the growing reemployability worries of their members, larger and more strike-prone unions are found to increase ALMP spending (corroborating H2), and specifically to increase those subdimensions that help union members, such as employment assistance and, especially, training. Third, unions' ALMP strategies are conditioned by the level of employment protection legislation: more powerful unions push up ALMP spending especially in those labor markets where jobs are not well protected (H3).

Cumulative evidence shows that union members wide across the OECD are especially worried about their re-employability chances in the event of job loss in the 1990s (Anderson \& Pontusson 2007) and in the 2000s (Figure 2). Moreover, members' support for ALMPs tends to increase where job protection levels are low (Nelson 2009). We have argued that union leaders, aware of the worries of their membership in case of job loss, today are more likely to use their clout to push for policies that boost workers' reemployment chances in low-EPL labor markets, where job turnover is high and firing and dismissal is easier. In such liberal and liberalizing market economies, ALMPs may simply turn into the first-best feasible union goal, as they are valued by their members as a form of re-employability security, yet can be framed as a market-strengthening policy tool.

As this study focuses on long-term structural changes, we have considered EPL as the exogenously given context in which leftwing governments and unions operate. EPL, however, can also be considered as a dependent variable - the result of strategic efforts 
by these actors to expand or consolidate insider protection. In this respect it further research might fruitfully investigate how union support for employment protection varies across the types of employment. Long-term trends of employment protection legislation for regular contracts (which largely correspond with insider jobs) and temporary contracts (outsider jobs) show a scissor-shaped pattern of a different kind from 1996 onwards. Regular contracts have enjoyed a remarkable status quo in protection levels; whereas temporary job contracts have suffered from reductions of protection levels. ${ }^{20}$ These findings are in line with Clayton and Pontusson's (1998) argument that unions (unlike leftwing parties) in globalized times are increasingly willing to condone or even support social spending cutbacks if this is likely to safeguard the status quo in terms of their labor market policy interests (see also Jensen 2012). Similarly, Davidsson and Emmenegger (2012) show that when it comes to job security legislation, unions tend to protect permanent contracts (which safeguards their members' interests) while simultaneously consenting in sometimes far-reaching further deregulation of temporary employment, which hurts labor market outsiders (see also Palier \& Thelen 2010). In sum, we suggest that unlike leftwing parties, unions today must still be viewed as primarily concerned with protecting labor market insider interests: through EPL when they can, but through ALMP spending when they must. 


\section{ACKNOWLEDGEMENT}

A previous version of this manuscript has been presented at the ECPR Joint Session in Sankt Gallen in April 2011 and at the European Centre General Assembly Meeting at the UN in Vienna in September 2011. For comments we are grateful to the participants, especially Johan Bo Davidsson, Bernd Marin, Pedro Ramos Pinto, Hans Steiner and Barbara Vis, as well as to Patrick Emmenegger. The dataset and Stata command files are available for replication.

\section{ENDNOTES}

${ }^{1}$ See, e.g., Armingeon (2007), Bonoli (2010), Weishaupt (2011). On the new political economy of skills, see Vanhuysse (2008).

${ }^{2}$ The partial exception (until the late 1990s) to this are 'Ghent system countries,' where unions are involved in social insurance administration, e.g. Nordic countries and Belgium (Ebbinghaus et al. 2011).

${ }^{3}$ See Rueda (2007: 14-15). The reason is that the social policy interests of insiders and outsiders are essentially opposed under tight fiscal conditions, as insiders want to improve or consolidate job protection and have few incentives to finance social programs that allow outsiders to find insider jobs and thus compete with them for jobs and wages.

${ }^{4}$ As discussed below, we define 'left values power' as: sqrt(Left ideology x Left cabinet seats).

${ }^{5}$ We thank two reviewers for pointing this out.

${ }^{6}$ Outside Nordic and Baltic Europe, women form the minority of union members in 12 out of 14 European nations. Women form a roughly equal portion of union members in a thirteenth European nation (Slovenia) (Eurofound 2009:19) and also in Canada (only) since the 2000s (Akyeampong 2004:6). Note, however, that greater 'women power' measured by economic participation and parliamentary representation levels does not appear to affect either family spending or ALMP spending (Tepe \& Vanhuysse 2010).

${ }^{7}$ For instance, coding 1972-2003 pension reform policy positions, Häusermann (2010) finds that unions attach a lower importance to postindustrial modernization than do left-wing parties. As a 
result, the unions-leftwing party distance increases and new 'modernizing compromises' tend to divide the left and to marginalize unions.

${ }^{8}$ The 'signs of the times,' in the form of widespread acceptance of the activation paradigm from the 1990s onwards, as well as continuing interaction of unions with modernizing leftwing parties may further contribute to refocus unions on those ALMP programs that at least serve their 'mainstream' members (those (self-)interested in re-employability protection), thereby perhaps diluting the influence of more left-leaning and/or ideologically motivated members. We thank a reviewer for urging us to clarify this.

${ }^{9}$ On ALMP preferences of union members, see Nelson (2009).

${ }^{10}$ Here too we expect a divergence between unions and leftwing parties. Leftwing parties in most OECD countries today have become more market-enhancing (less anti-liberal) than unions in their labor market policies, and they have widened or diversified their policy stances to cater for a more heterogeneous middle class. These parties' stance towards ALMPs is therefore not likely to be much affected by the degree to which insiders are protected already by EPL.

${ }^{11}$ Note that Japan is not affiliated to any of these four regimes.

${ }^{12}$ Franzmann and Kaiser (2006:165) show that the ideological left-right scale is among the most important dimensions of the political space. It is understood as compound scale, measuring economic perceptions (pro-market liberalism vs. state protectionism) and non-economic issues such as culture, crime prevention, education, women's rights, or integration of immigrants, and so on.

${ }^{13}$ See http://stats.oecd.org/glossary/detail.asp?ID=3535

${ }^{14}$ While the use of cross-sectional time-series data has become paramount in macro-comparative research on the welfare state (e.g. Table 1), such data is flawed by a multitude of methodological issues (Kittel 2008). Substantive issues like learning and policy feedback impact on the possibility to make inferential statements whereas technical issues like nonstationarity and serial correlation limit the ability to interpret estimates obtained from regression models (Kittel 2008:29). We thus note that our statistical models cannot be understood as causal models in the strict sense, but rather as an exploration of the statistical associations derived from a heuristic framework of hypotheses.

${ }^{15}$ Before the independent variables enter the statistical models they have been tested for multicollinearity using the Variance Inflation Factor, whose mean values for the full set of variables is 1.65 , with a maximum of 2.06 and a minimum of 1.04 , all of which are considered as unproblematic values. 
${ }^{16}$ See e.g. Bonoli (2010), Weishaupt (2011), Armingeon (2007). In the case of Anglo-Saxon countries such as the UK, Australia and the US, this was combined with a greater emphasis on workfare programs from the late 1990s.

${ }^{17}$ In order to make sure that these findings are not driven by the cross-sectional composition of the panel dataset we run a Jackknife test on Model 7 from Table 3, and on Model 5 and 10 in Appendix Table 3. The results (Appendix Table 4) confirm that the size of the effect of strike activity and of left values power varies with the cross-sectional composition of the panel dataset. More importantly, the direction of these effects is robust. To conduct the Panel Jackknife Test we use the xtjack command in Stata programmed by Kittel (2001).

${ }^{18}$ To prepare marginal effect plots we use the margeff command in Stata (Kittel 2006).

${ }^{19}$ This finding simultaneously casts some doubt on the view that ALMPs are an unambiguous labor market outsider program, as much of the literature in economics and political science generally assumes (Saint-Paul 2000; Rueda 2005, 2006, 2007; Iversen 2005; Lindbeck \& Snower 1988, 2001).

${ }^{20}$ OECD data (not shown, available on request). 


\section{REFERENCES}

Akyeampong, E.B. (2004), 'The Union Movement in Transition,' Statistics Canada Perspectives on Labor and Income: 16(2):1-14.

Anderson, C., Pontusson, J. (2007), ‘Workers, Worries and Welfare States: Social Protection and Job Insecurity in 15 OECD Countries,' European Journal of Political Research 46:211-235.

Armingeon, K., Weisstanner, D., Engler, S., Potolidis, P., Gerber, M. and Leimgruber, P. (2011) Comparative Political Dataset 1960-2009. Berne University

Armingeon, K. (2007), 'ALMP, International Organizations, and Domestic Politics,' Journal of European Public Policy, 14(6):905-932.

Bonoli, G. (2010), 'The Political Economy of ALMP,' Politics \& Society, 38(4):435-457.

Bonoli, G., Reber, F. (2010), 'The Political Economy of Childcare in OECD Countries: Explaining Crossnational Variation in Spending and Coverage Rates, European Journal of Political Research 49(2):97-118.

Boix, C. (1998), Political Parties, Growth, and Equality. New York: Cambridge University Press.

Brandl, B., Traxler, F. (2010), 'Labour Conflicts: A Cross-national Analysis of Economic and Institutional Determinants, 1971-2002,' European Sociological Review 26(5): 519540.

Breusch, T., Ward, M., Nguyen H., Kompas T. (2011) 'FEVD: Just IV or Just Mistaken?' Political Analysis, 19(2): 165-169.

Budge, I., Klingemann, H-D., Volkens, A., Bara, J., Tanenbaum, E (2001). Mapping Policy Preferences: Estimates for Parties, Electors, and Governments 1945-1998. Oxford: OUP. 
Calmfors, L., Driffill, J. (1988), 'Bargaining Structure, Corporatism, and Macroeconomic Performance,' Economic Policy 6:13-61.

Chung, H, van Oorschot, W. (2011), 'Institutions versus market forces: Explaining the employment insecurity of European individuals during (the beginning of) the financial crisis,' Journal of European Social Policy 21(3)::287-301

Clayton, M., Pontusson, J. (21998), 'Welfare Retrenchment Revisited: Entitlement Cuts, Public Sector Restructuring and Inegalitarian Trends in Advanced Capitalist Societies,' World Politics 51(1):67-98.

Davidsson, J., Emmenegger, P. (2012), 'Insider-Outsider Dynamics and the Reform of Job Security Legislation,' in Bonoli, G. and Natali, D. (eds) The Politics of the New Welfare State, OUP, forthcoming.

Ebbinghaus, B, Goebel, C., Koos, S. (2011), 'Social capital, 'Ghent' and workplace contexts matter: Comparing union membership in Europe,' European Journal of Industrial Relations, 17(2):107-124.

Emmenegger, P. (2009), 'Barriers to Entry: Insider/Outsider Politics and the Determinants of Job Security Regulations,'Journal of European Social Policy 19(2):131-146

Esping-Andersen, G. (1990) The Three Worlds of Welfare Capitalism. Cambridge: Polity Press.

Esping-Andersen, G. (2009) The Unfinished Revolution. Cambridge: Polity Press.

Eurofound (2009), Trade Union Membership, 2003-2008. Dublin: Eurofound.

Gaston, N., Rajaguruy, G. (2008) 'The Rise (and Fall) of Labour Market Programmes: Domestic vs. Global Factors,' Oxford Economics Papers 60:619-648.

Golden, M.A. (1992), 'The Politics of Job Loss,' American Journal of Political Science $36: 408-430$.

Halaby, C. (2004), 'Panel Models in Sociological Research,' Annual Review of Sociology 30: $507-544$. 
Häusermann, S., Schwander, H. (2009), 'Identifying Outsiders across Countries: Similarities and Differences in the Patterns of Dualization,' RECWOWE paper 09/2009.

Huo, J., Nelson, M., Stephens, J.D. (2008), 'Decommodification and Activation in Social Democratic Policy,' Journal of European Social Policy 18(1): 5-20.

Iversen, T. (2005) Democracy, Capitalism, and Welfare. Cambridge: CUP.

Iversen, T., Stephens, J.D. (2008), 'Partisan Politics, the Welfare State, and Three Worlds of Human Capital Formation,' Comparative Political Studies 41(4-5):600-637.

Janoski, T. (1994), 'Direct State Intervention in the Labor Market,' in Janoski, T and Hicks, A. (eds), The Comparative Political Economy of the Welfare State. New York: Cambridge University Press.

Jensen, C. (2012), 'Two Sides of the Same Coin? Left-Wing Governments and Labour Unions as Determinants of Public Spending,' forthcoming, Socio-Economic Review.

Kittel, B. (2001). xtjack - Jackknife Analysis for Panel Data, Max Planck Institute for the Study of Societies, Cologne, Germany.

Kittel, B. (2006). margeff - Interaction analysis for regression results, University of Amsterdam, Netherlands.

Kittel, B. (2008), 'Statistical Narratives and the Properties of Macro-Level Variables,' in Kenworthy, L. and Hicks. A. (Eds.), Method and Substance. Houndmills: Palgrave Macmillan.

Klingemann, H-D. Volkens, A., Bara, J., Budge, I., Mc- Donald, M. (2006), Mapping Policy Preferences II. Oxford: OUP.

Korpi, W. (1983) The Democratic Class Struggle. London: Routledge and Kegan. 
Laver, M., Budge, I. (1992) (eds.) Party Policy and Government Coalitions, Houndmills, Basingstoke, Hampshire: The MacMillan Press

Lindbeck, A., Snower, D. (1988), The Insider-Outsider Theory of Employment and Unemployment. Cambridge: MIT Press.

Lindbeck, A., Snower, D. (2001), 'Insiders versus Outsiders,' Journal of Economic Perspectives 15(1):165-188.

Näswall, K., Chirumbolo, A., De Witte, H., \& Gosling, S. (2004). Job Insecurity and Union Membership. Brussels: Peter Lang.

Nelson, M. (2009), 'An Application of the Estimated Dependent Variable Approach: Trade Union Members' Support for ALMPs and Insider-Outsider Politics,' International Journal of Public Opinion Research 21(2):224-234.

OECD (2010) Indicators of Employment Protection,

http://www.oecd.org/document/11/0,3746,en_2649 $37457 \quad 42695243 \quad 1 \quad 1 \quad 1 \quad 37457,00 . h t m l$ \#methodoly.

OECD (2011) Employment and Labour Market Statistics, http://www.oecdilibrary.org/employment/data/labour-force-statistics lfs-lfs-data-en.

OECD (2011) Social Expenditure Database, http://www.oecd.org/document/9/0,3746,en $2649 \quad 34637 \quad 38141385 \quad 1 \quad 1 \quad 1 \quad 1,00 . h t$ $\underline{\mathrm{ml}}$.

Olson, M. (1981) The Rise and Decline of Nations. New Haven: Yale University Press.

Palier, B., Thelen, K (2010), 'Institutionalizing Dualism: Complementarities and Change in France and Germany,' Politics \& Society 38:119-136. 
Rueda, D. (2005) 'Insider-Outsider Politics in Industrialized Democracies: The Challenge to Social Democratic Parties,' American Political Science Review 99(1):61-74.

Rueda, D. (2006), 'Social Democracy and ALMPs: Insiders, Outsiders and the Politics of Employment Protection,' British Journal of Political Science 35:385-406.

Rueda, D. (2007) Social Democracy Inside Out, Oxford: Oxford University Press.

Saint-Paul. G. (2000) The Political Economy of Labour Market Institutions, Oxford University Press.

Seeleib-Kaiser, M., van Dyke, S. Roggenkamp, M. (2009), Party Politics and Social Welfare. Northampton: Edward Elgar.

Tepe, M., Vanhuysse, P. (2010) 'Elderly Bias, New Social Risks, and Social Spending: Change and Timing in Eight Programs across Four Worlds of Welfare, 1980-2003', Journal of European Social Policy, 20(3):218-34.

Traxler, F., Brandl, B. (2010), 'Collective Bargaining, Macroeconomic Performance, and the Sectoral Composition of Trade Unions,' Industrial Relations 49(1):91-115.

Upchurch, M., Taylor, G., Mathers, A (2009) The Crisis of Social Democratic Trade Unionism in Western Europe. Ashgate, Farnham.

Vanhuysse, P. (2006), Divide and Pacify: Strategic Social Policies and Political Protests in Post-communist Democracies. Budapest-New York: Central European University Press.

Vanhuysse, P. (2008), 'The New Political Economy of Skill Formation,' Public Administration Review, 68(5): 955-959. 
Vanhuysse, P., Sulitzeanu-Kenan, R. (2009), 'Teacher's PAT? Multiple-Role PrincipalAgent Theory, Education Politics, and the Power of Bureaucrats,' Critical Studies in Education 50(2): 129-144.

Vlandas, T. (2011) 'The Dependent Variable Problem in Quantitative Studies of Active Labour Market Programmes: Uncovering Hidden Dynamics?,' RECWOWE paper $03 / 2011$

Vliet, O., Koster, F. (2011), 'Europeanization and the Political Economy of ALMPs,' European Union Politics 12(2):217-239.

Volkens, A., Lacewell, O., Lehmann, P., Regel, S., Schultze, H., Werner, A. (2011), The Manifesto Data Collection. Manifesto Project, Berlin: WZB.

Weishaupt, T. (2011), From the Manpower Revolution to the Activation Paradigm. Amsterdam: Amsterdam University Press. 
Figure 1. Long-term trends in industrial employment, leftwing cabinet posts and union density

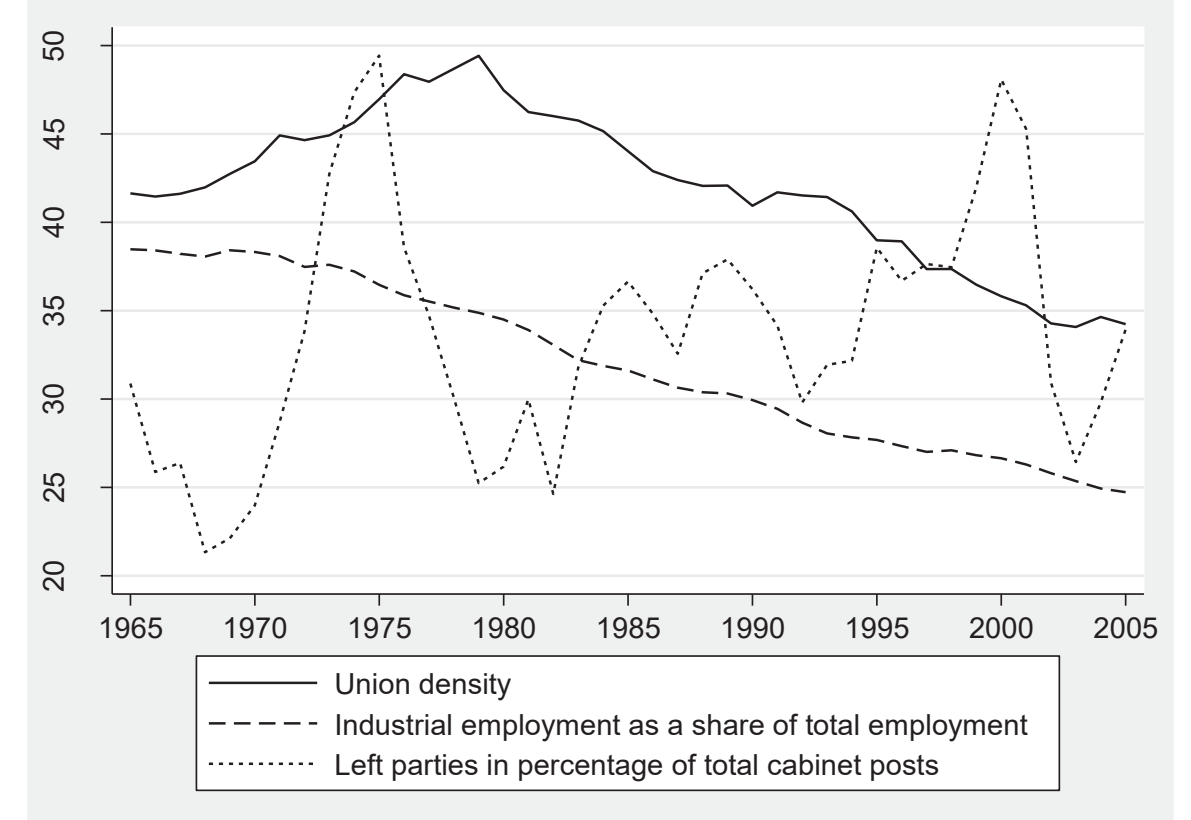

Note: Average values for 20 OECD countries 
Figure 2. Job worries and re-employability worries among union members and non-members (2005)

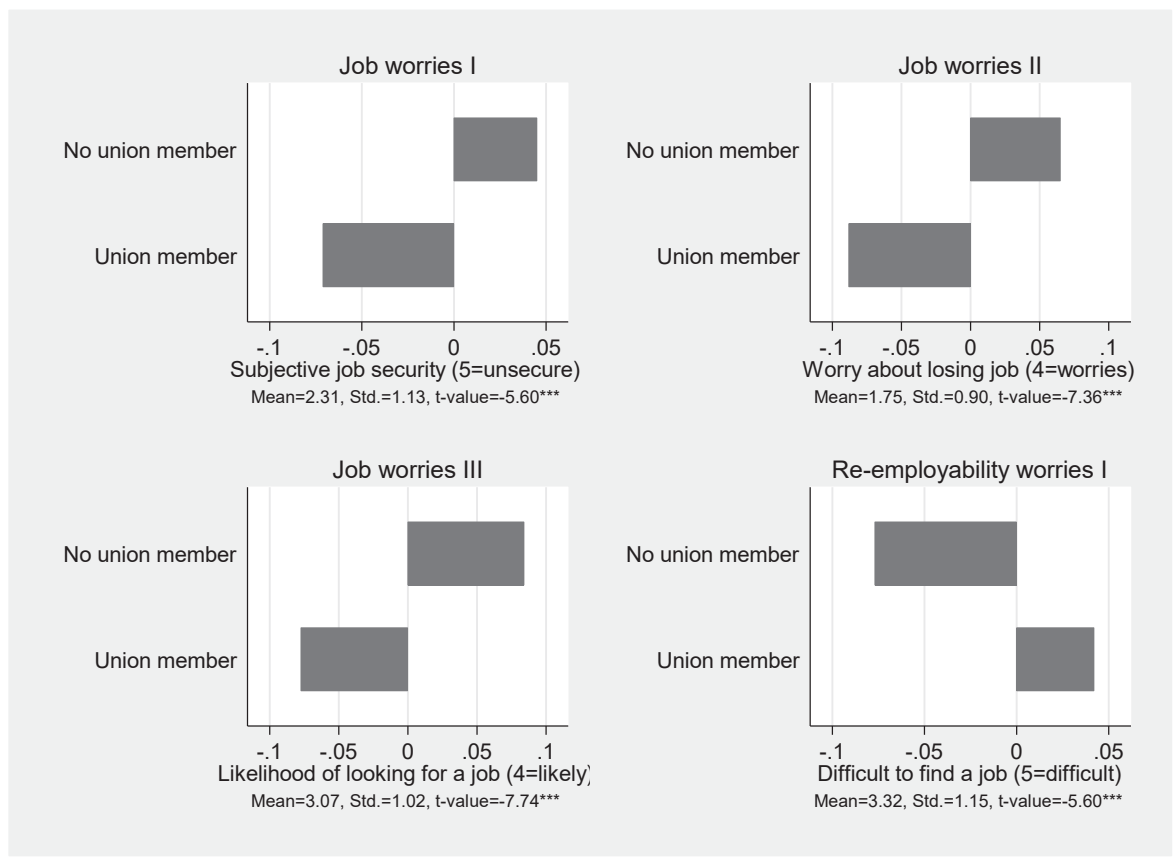

Note: Weighted average for 17 OECD countries (z-standardized values, Mean and Std. refer to the original scale) t-value $=$ Two-group mean-comparison test (Union member vs. No union member). Source: International Social Survey Program (2005) Module Work Orientations III (ZA 4350, N=10624). Variables: Job worries-I: 'How much do you agree or disagree: my (main) job is secure' (V29), Job worries-II: 'To what extent, if at all, do you worry about the possibility of losing your job?' (V58), Job worries-III: 'All in all, how likely is it that you will try to find a job with another firm or organization within the next 12 months?' (V57), Re-employability worries-I: 'How difficult or easy do you think it would be for you to find a job at least as good as your current one?' (V55). 
Table 1. Existing studies on ALMP spending

\begin{tabular}{|c|c|c|c|c|c|c|}
\hline Author(s) & $\mathbf{N}$ & $\mathbf{T}$ & Model & $\begin{array}{l}\text { Dependent } \\
\text { variable }\end{array}$ & Impact of politics & Control measures \\
\hline $\begin{array}{l}\text { Rueda } \\
(2005)\end{array}$ & 16 & 1973-96 & PCSE, RE & ALMP/GDP & $\begin{array}{l}\text { Cabinet partisanship }(+) \text {, Union density }(+ \text {, } \\
\text { sig.), Bargaining centralization }(+)\end{array}$ & $\begin{array}{l}\text { International openness }(+, \\
\text { sig.), Debt }(+, \text { sig. }) \\
\text { Unemployment }(+)\end{array}$ \\
\hline $\begin{array}{l}\text { Franzese \& } \\
\text { Hays (2006) }\end{array}$ & 15 & 1987-98 & $\begin{array}{l}\text { Spatial Lag, } \\
\text { FE }\end{array}$ & $\begin{array}{l}\text { Labor market } \\
\text { training } \\
\text { expenditures per } \\
\text { unemployed worker }\end{array}$ & $\begin{array}{l}\text { Left cabinet (-), Right cabinet (-), Union } \\
\text { density (null) }\end{array}$ & $\begin{array}{l}\text { Trade openness (+, sig.), } \\
\text { Unemployment }(-, \text { sig.), } \\
\text { Government consumption }(+, \\
\text { sig.) }\end{array}$ \\
\hline $\begin{array}{l}\text { Rueda } \\
(2007)\end{array}$ & 18 & $1980-98$ & PCSE, RE & ALMP/GDP & $\begin{array}{l}\text { Left government (-, sig.), Union density } \\
(+), \text { Employment protection }(+), \text { Wage } \\
\text { bargaining coordination }(+) \text {, Change in } \\
\text { Left government X Employment protection } \\
(-, \text { sig.), Change in Left government X } \\
\text { wage bargaining coordination (-). }\end{array}$ & $\begin{array}{l}\text { Trade openness }(+, \text { sig), } \\
\text { Deficit (-,sig), Growth (-, sig.), } \\
\text { Unemployment (+) }\end{array}$ \\
\hline $\begin{array}{l}\text { Armingeon } \\
(2007)\end{array}$ & 22 & 1985-02 & $\begin{array}{l}\text { First difference } \\
\text { PCSE }\end{array}$ & $\begin{array}{l}\text { Change in ALMP } \\
\text { spending as a } \\
\text { share of labor } \\
\text { market policy }\end{array}$ & $\begin{array}{l}\text { Left parties in government (null), } \\
\text { Continental welfare state }(+, \text { sig.), Nordic } \\
\text { welfare state }(+)\end{array}$ & $\begin{array}{l}\text { GDP growth (+, sig.), Change } \\
\text { in Unemployment (-, sig.), } \\
\text { Import and Export per GDP (-, } \\
\text { sig.) }\end{array}$ \\
\hline $\begin{array}{l}\text { Iversen \& } \\
\text { Stephens (2008) }\end{array}$ & 18 & n.a. & $\begin{array}{l}\text { PCSE, AR1 } \\
\text { corr. }\end{array}$ & $\begin{array}{l}\text { ALMP spending per } \\
\text { unemployed }\end{array}$ & $\begin{array}{l}\text { Left cabinet }(+, \text { sig.), Christian Democratic } \\
\text { cabinet (null) Authoritarian legacy }(+, \text { sig.), } \\
\text { Strikes (-) }\end{array}$ & $\begin{array}{l}\text { Percentage of aged persons (- } \\
\text { sig.), GDP per capita (+, sig.), } \\
\text { Trade Openness (null) }\end{array}$ \\
\hline $\begin{array}{l}\text { Gaston \& } \\
\text { Rajaguru (2008) }\end{array}$ & 16 & 1980-99 & Panel VAR & ALMP/GDP & Left $(-)$ & $\begin{array}{l}\text { Debt }(-, \text { sig.), Dependency } \\
\text { ratio }(-, \text { sig.), } \\
\text { Openness (+) }\end{array}$ \\
\hline $\begin{array}{l}\text { Huo, Nelson \& } \\
\text { Stephens (2008) }\end{array}$ & 18 & $1980-98$ & $\begin{array}{l}\text { OLS (clustered } \\
\text { by country) }\end{array}$ & $\begin{array}{l}\text { ALMP spending per } \\
\text { unemployed }\end{array}$ & $\begin{array}{l}\text { Left cabinet }(+, \text { sig. }) \text {, Authoritarian legacy } \\
(+, \text { sig. })\end{array}$ & $\begin{array}{l}\text { Trade openness (null), GDP } \\
\text { per capita }(+, \text { sig.) }\end{array}$ \\
\hline $\begin{array}{l}\text { Tepe \& Van- } \\
\text { huysse }(2010)\end{array}$ & 21 & $1980-03$ & $\begin{array}{l}\text { OLS, FE, } \\
\text { period effects }\end{array}$ & ALMP/GDP & Nordic welfare state $(+$, sig. $)$ & $\begin{array}{l}\text { Deficit (-, sig.), ODR (null), } \\
\text { Unemployment }(+)\end{array}$ \\
\hline Vlandas (2011) & 15 & $1985-07$ & $\begin{array}{l}\text { FE (Time, } \\
\text { Country) }\end{array}$ & ALMP/GDP & $\begin{array}{l}\text { Left }(-) \text {, Union density }(+, \text { sig. }) \text {, Degree of } \\
\text { wage coordination }(+, \text { sig. }), \text { Employment } \\
\text { protection }(+)\end{array}$ & $\begin{array}{l}\text { Deficit (-, sig.) Unemployment } \\
(+) \text {, Growth (-), Trade } \\
\text { openness (-) }\end{array}$ \\
\hline $\begin{array}{l}\text { Van Vliet \& } \\
\text { Koster (2011) }\end{array}$ & 22 & 1985-05 & PCSE, FE & $\begin{array}{l}\text { ALMP (\% of labor } \\
\text { market spending) }\end{array}$ & Right cabinet seats $(-$, sig. $)$ & $\begin{array}{l}\text { Government deficit (-, sig.), } \\
\text { Unemployment (-, sig.), GDP } \\
\text { per capita (+, sig), Economic } \\
\text { openness }(+, \text { sig.) }\end{array}$ \\
\hline
\end{tabular}


Table 2. Types of ALMP spending and main independent variables (1985-2005)

\begin{tabular}{|c|c|c|c|c|c|c|c|c|}
\hline \multirow[t]{2}{*}{ Country } & \multicolumn{3}{|c|}{ ALMP spending } & \multicolumn{2}{|c|}{ Incumbent parties } & \multicolumn{2}{|c|}{ Union clout } & \multirow{2}{*}{$\begin{array}{c}\text { Inst. context } \\
\text { EPL }\end{array}$} \\
\hline & per GDP & $\begin{array}{c}\text { per } \\
\text { unemployed }\end{array}$ & $\begin{array}{l}\text { share of } \\
\text { PLMP }\end{array}$ & $\begin{array}{l}\text { Left cabinet } \\
\text { share }\end{array}$ & $\begin{array}{l}\text { Extreme right }(0) \\
\text { to extreme left } \\
\text { ideology }(100)\end{array}$ & $\begin{array}{l}\text { Strike } \\
\text { activity }\end{array}$ & $\begin{array}{l}\text { Union } \\
\text { density }\end{array}$ & \\
\hline Australia & 35.7 & 1.1 & 33.1 & 51.0 & -13.9 & 101.2 & 32.1 & 1.07 \\
\hline Canada & 45.3 & 1.2 & 37.5 & 0.0 & -6.2 & 228.1 & 32.8 & 0.75 \\
\hline Ireland & 103.2 & 1.6 & 69.4 & 11.1 & 2.7 & 89.7 & 49.0 & 0.96 \\
\hline New Zealand & 61.2 & 1.7 & 48.0 & 54.5 & 17.1 & 99.4 & 32.3 & 1.04 \\
\hline UK & 49.4 & 0.6 & 54.9 & 43.3 & -19.1 & 46.0 & 34.8 & 0.64 \\
\hline USA & 14.6 & 0.5 & 36.6 & 0.0 & -23.5 & 45.3 & 14.3 & 0.21 \\
\hline Anglo-Saxon & 51.6 & 1.1 & 46.6 & 26.7 & -7.2 & 101.6 & 32.6 & 0.78 \\
\hline Austria & 40.5 & 1.7 & 37.7 & 35.5 & -9.7 & 19.5 & 41.2 & 2.17 \\
\hline Belgium & 101.8 & 1.9 & 33.3 & 46.2 & 6.1 & 43.5 & 53.0 & 2.71 \\
\hline France & 94.3 & 1.5 & 54.7 & 45.0 & 4.9 & 26.5 & 9.4 & 2.94 \\
\hline Germany & 98.9 & 1.8 & 69.3 & 35.6 & -7.8 & 6.0 & 28.5 & 2.74 \\
\hline Netherlands & 83.4 & 1.9 & 40.9 & 26.9 & 2.4 & 13.4 & 23.9 & 2.52 \\
\hline Switzerland & 28.8 & 2.3 & 42.3 & 28.6 & -4.1 & 1.8 & 22.4 & 1.14 \\
\hline Continental & 74.6 & 1.8 & 46.3 & 36.3 & -1.4 & 18.5 & 29.7 & 2.37 \\
\hline Denmark & 114.7 & 4.2 & 31.7 & 33.0 & -12.0 & 94.3 & 75.0 & 1.91 \\
\hline Finland & 100.4 & 1.6 & 42.4 & 39.2 & 11.0 & 163.3 & 75.5 & 2.15 \\
\hline Norway & 69.3 & 4.5 & 93.0 & 60.7 & 13.6 & 82.8 & 56.2 & 2.75 \\
\hline Sweden & 164.7 & 4.9 & 118.7 & 85.0 & 2.1 & 51.8 & 82.2 & 2.72 \\
\hline Nordic & 112.2 & 3.8 & 71.5 & 54.5 & 3.7 & 98.1 & 72.2 & 2.38 \\
\hline Italy & 40.7 & 0.5 & 74.7 & 26.6 & -12.4 & 123.6 & 37.0 & 3.00 \\
\hline Portugal & 47.7 & 0.5 & 74.6 & 26.1 & 12.9 & 26.8 & 25.0 & 3.82 \\
\hline Spain & 58.8 & 0.2 & 23.0 & 60.2 & 4.4 & 260.3 & 14.9 & 3.32 \\
\hline Southern & 49.1 & 0.4 & 57.5 & 37.6 & 1.6 & 136.9 & 25.6 & 3.38 \\
\hline Japan & 30.4 & 6.5 & 66.9 & 5.0 & 4.3 & 1.7 & 23.5 & 1.66 \\
\hline Overall mean & 69.2 & 2.0 & 54.1 & 35.7 & -1.4 & 76.3 & 38.2 & 2.01 \\
\hline Coefficient of Variation & 0.6 & 0.9 & 0.5 & 1.0 & -11.6 & 1.3 & 0.6 & 0.52 \\
\hline
\end{tabular}


Table 3. Regression analysis: ALMP spending per GDP

\begin{tabular}{|c|c|c|c|c|c|c|c|}
\hline & $\begin{array}{c}\text { Model } 1 \\
\text { BE }\end{array}$ & $\begin{array}{c}\text { Model } 2 \\
\text { FE }\end{array}$ & $\begin{array}{c}\text { Model } 3 \\
\text { FE }\end{array}$ & $\begin{array}{c}\text { Model } 4 \\
\text { FE }\end{array}$ & $\begin{array}{c}\text { Model } 5 \\
\text { FE }\end{array}$ & $\begin{array}{c}\text { Model } 6 \\
\text { FE }\end{array}$ & $\begin{array}{c}\text { Model } 7 \\
\text { FE }\end{array}$ \\
\hline \multirow[t]{2}{*}{ GDP growth } & 0.001 & 0.003 & 0.004 & 0.006 & 0.019 & 0.018 & 0.033 \\
\hline & [0.04] & {$[0.04]$} & [0.04] & [0.04] & [0.04] & [0.03] & [0.04] \\
\hline \multirow[t]{2}{*}{ Deficit } & $-0.0789^{*}$ & $-0.0828^{*}$ & $-0.0823^{*}$ & $-0.0861^{*}$ & $-0.0886^{* *}$ & $-0.0820^{* *}$ & $-0.0936^{* *}$ \\
\hline & [0.04] & [0.04] & [0.04] & [0.04] & [0.04] & [0.04] & [0.03] \\
\hline \multirow[t]{2}{*}{ Openness } & $0.162^{* * *}$ & -0.0271 & -0.0352 & -0.0316 & -0.0630 & -0.0735 & -0.105 \\
\hline & [0.04] & [0.13] & [0.13] & [0.12] & [0.11] & [0.09] & {$[0.08]$} \\
\hline \multirow[t]{2}{*}{ Unemployment rate } & $0.149^{* * *}$ & 0.0468 & 0.0379 & 0.0439 & 0.0207 & 0.0584 & 0.0342 \\
\hline & [0.04] & {$[0.05]$} & {$[0.05]$} & {$[0.05]$} & {$[0.05]$} & {$[0.04]$} & {$[0.03]$} \\
\hline \multirow[t]{2}{*}{ Conservative } & 0.142 & & & & & & \\
\hline & [0.10] & & & & & & \\
\hline \multirow[t]{2}{*}{ Scandinavia } & $0.639^{* * *}$ & & & & & & \\
\hline & {$[0.10]$} & & & & & & \\
\hline \multirow[t]{2}{*}{ Southern } & -0.126 & & & & & & \\
\hline & {$[0.11]$} & & & & & & \\
\hline \multirow[t]{2}{*}{ Left cabinet share } & & -0.0128 & & & & & \\
\hline & & [0.02] & & & & & \\
\hline \multirow[t]{2}{*}{ Ideological position } & & & $-0.0548^{*}$ & & & & \\
\hline & & & [0.03] & & & & \\
\hline \multirow[t]{2}{*}{ Left values power } & & & & -0.0334 & & & -0.0372 \\
\hline & & & & [0.03] & & & [0.02] \\
\hline \multirow[t]{2}{*}{ Union density } & & & & & $0.361^{* *}$ & & $0.252^{* \star}$ \\
\hline & & & & & [0.13] & & [0.11] \\
\hline \multirow[t]{2}{*}{ Strike activity } & & & & & & $0.190^{* * *}$ & $0.163^{* * *}$ \\
\hline & & & & & & {$[0.05]$} & [0.04] \\
\hline \multirow[t]{2}{*}{ 1991-95 } & & 0.111 & $0.124^{*}$ & $0.112^{*}$ & $0.163^{* *}$ & $0.172^{* * *}$ & $0.200^{* * *}$ \\
\hline & & {$[0.07]$} & {$[0.06]$} & {$[0.06]$} & {$[0.06]$} & [0.05] & [0.05] \\
\hline \multirow[t]{2}{*}{$1996-00$} & & $0.223^{*}$ & $0.217^{*}$ & $0.222^{*}$ & $0.326^{* *}$ & $0.328^{* * *}$ & $0.390^{* * *}$ \\
\hline & & {$[0.12]$} & {$[0.11]$} & {$[0.12]$} & [0.12] & [0.09] & [0.10] \\
\hline \multirow[t]{2}{*}{ 2001-05 } & & 0.128 & 0.123 & 0.125 & $0.284^{* *}$ & $0.279^{* * *}$ & $0.367^{* * *}$ \\
\hline & & {$[0.12]$} & [0.12] & {$[0.12]$} & {$[0.11]$} & {$[0.10]$} & {$[0.10]$} \\
\hline Observations & 76 & 80 & 80 & 80 & 80 & 80 & 80 \\
\hline Adjusted R-squared & 0.536 & 0.238 & 0.282 & 0.259 & 0.336 & 0.394 & 0.454 \\
\hline $\mathrm{AIC}$ & 29.43 & -60.30 & -65.08 & -62.54 & -71.32 & -78.67 & -85.32 \\
\hline $\mathrm{BIC}$ & 48.07 & -41.24 & -46.03 & -43.49 & -52.27 & -59.61 & -61.50 \\
\hline
\end{tabular}

Note: $\mathrm{BE}=$ Between countries effects, $\mathrm{FE}=$ Country fixed effects robust standard errors in brackets, ${ }^{*} \mathrm{p}<0.10$, $* * \mathrm{p}<0.05, * * * \mathrm{p}<0.001$, constant included but not reported. 
Table 4. Regression analysis: public spending per GDP on Job Creation, Training, and Employment Assistance

\begin{tabular}{|c|c|c|c|c|c|c|c|c|c|}
\hline & Model 1 & Model 2 & Model 3 & Model 4 & Model 5 & Model 6 & Model 7 & Model 8 & Model 9 \\
\hline & & Job Creation & & & Training & & \multicolumn{3}{|c|}{ Employment Assistance } \\
\hline \multirow[t]{2}{*}{ GDP growth } & 0.007 & 0.007 & 0.006 & -0.007 & 0.000 & 0.000 & 0.006 & 0.012 & 0.0115 \\
\hline & {$[0.02]$} & {$[0.02]$} & {$[0.02]$} & {$[0.02]$} & {$[0.02]$} & {$[0.02]$} & {$[0.01]$} & {$[0.02]$} & {$[0.02]$} \\
\hline \multirow[t]{2}{*}{ Deficit } & $-0.0271^{*}$ & -0.0247 & -0.0237 & -0.0228 & -0.0249 & -0.0216 & -0.0362 & -0.0390 & -0.0367 \\
\hline & [0.01] & [0.02] & [0.02] & [0.02] & [0.02] & [0.02] & [0.03] & [0.02] & {$[0.02]$} \\
\hline \multirow[t]{2}{*}{ Openness } & -0.007 & -0.007 & -0.007 & -0.049 & -0.066 & -0.073 & 0.024 & 0.010 & 0.006 \\
\hline & [0.04] & [0.05] & {$[0.05]$} & [0.08] & {$[0.07]$} & [0.06] & {$[0.06]$} & [0.05] & {$[0.05]$} \\
\hline \multirow[t]{2}{*}{ Unempl. rate } & -0.0178 & -0.0195 & -0.0143 & $0.0549^{*}$ & 0.0425 & $0.0620^{* *}$ & 0.00687 & -0.00226 & 0.0106 \\
\hline & [0.02] & [0.02] & [0.02] & [0.03] & {$[0.03]$} & [0.02] & [0.02] & [0.02] & {$[0.02]$} \\
\hline \multirow[t]{2}{*}{ Left val. power } & $-0.021^{* *}$ & & & -0.012 & & & 0.000 & & \\
\hline & [0.01] & & & {$[0.01]$} & & & {$[0.01]$} & & \\
\hline \multirow[t]{2}{*}{ Union density } & & 0.0531 & & & $0.185^{\star *}$ & & & 0.123 & \\
\hline & & {$[0.06]$} & & & {$[0.07]$} & & & {$[0.07]$} & \\
\hline \multirow[t]{2}{*}{ Strike activity } & & & 0.0224 & & & $0.102^{* \star *}$ & & & $0.0654^{*}$ \\
\hline & & & {$[0.02]$} & & & [0.02] & & & [0.03] \\
\hline \multirow[t]{2}{*}{$1991-95$} & 0.042 & 0.049 & 0.049 & 0.014 & 0.040 & 0.046 & $0.056^{* *}$ & $0.0737^{* *}$ & $0.0772^{* *}$ \\
\hline & {$[0.03]$} & {$[0.03]$} & {$[0.03]$} & {$[0.04]$} & {$[0.04]$} & [0.03] & [0.02] & [0.03] & [0.03] \\
\hline \multirow[t]{2}{*}{$1996-00$} & 0.0517 & 0.0659 & 0.0630 & 0.0702 & $0.124^{*}$ & $0.128^{* *}$ & $0.0999^{*}$ & $0.136^{* \star}$ & $0.137^{* *}$ \\
\hline & {$[0.03]$} & {$[0.05]$} & {$[0.04]$} & {$[0.06]$} & {$[0.06]$} & {$[0.05]$} & {$[0.05]$} & {$[0.06]$} & {$[0.05]$} \\
\hline \multirow[t]{2}{*}{ 2001-05 } & -0.020 & 0.004 & -0.001 & 0.033 & 0.115 & $0.116^{*}$ & $0.111^{*}$ & $0.165^{* *}$ & $0.164^{* *}$ \\
\hline & {$[0.04]$} & {$[0.06]$} & {$[0.05]$} & {$[0.07]$} & {$[0.07]$} & {$[0.06]$} & {$[0.06]$} & {$[0.07]$} & {$[0.06]$} \\
\hline Observations & 80 & 80 & 80 & 80 & 80 & 80 & 80 & 80 & 80 \\
\hline Adj. R-squared & 0.154 & 0.108 & 0.109 & 0.213 & 0.310 & 0.391 & 0.236 & 0.284 & 0.314 \\
\hline AIC & -194.5 & -190.4 & -190.4 & -172.0 & -182.5 & -192.6 & -173.8 & -179.1 & -182.5 \\
\hline $\mathrm{BIC}$ & -175.5 & -171.3 & -171.3 & -153.0 & -163.5 & -173.5 & -154.7 & -160.0 & -163.4 \\
\hline
\end{tabular}

Note: Country fixed effects robust standard errors in brackets, $* \mathrm{p}<0.10, * * \mathrm{p}<0.05, * * * \mathrm{p}<0.001$, constant included but not reported 
Figure 3. Effect of left values power and union power on ALMP spending, as conditioned by EPL

\section{ALMP per GDP predicted}
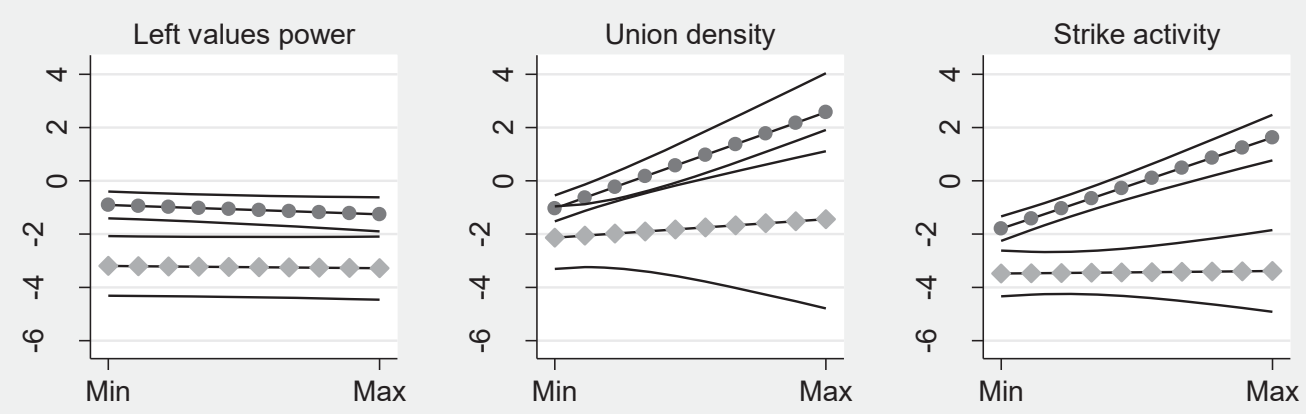

ALMP/Unempl. predicted
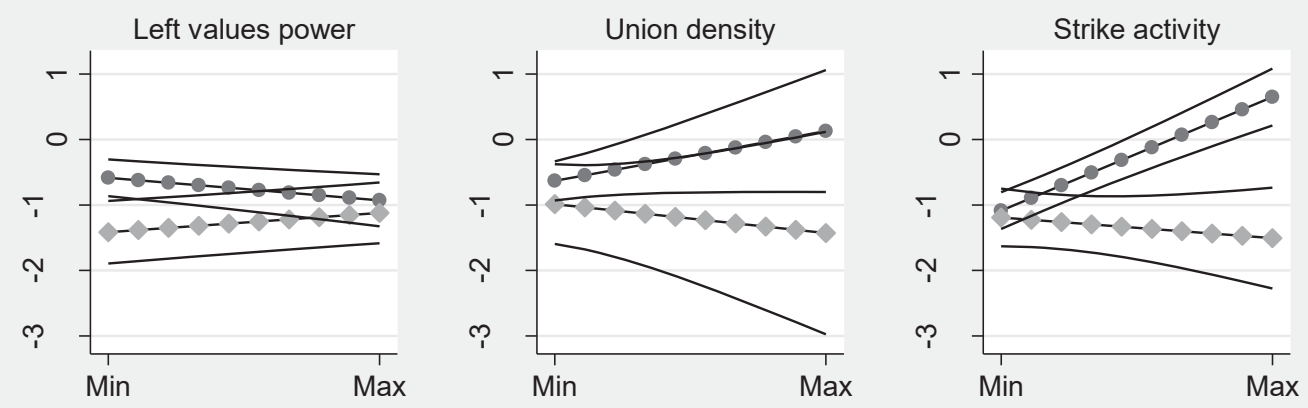

\section{ALMP/Passive predicted}
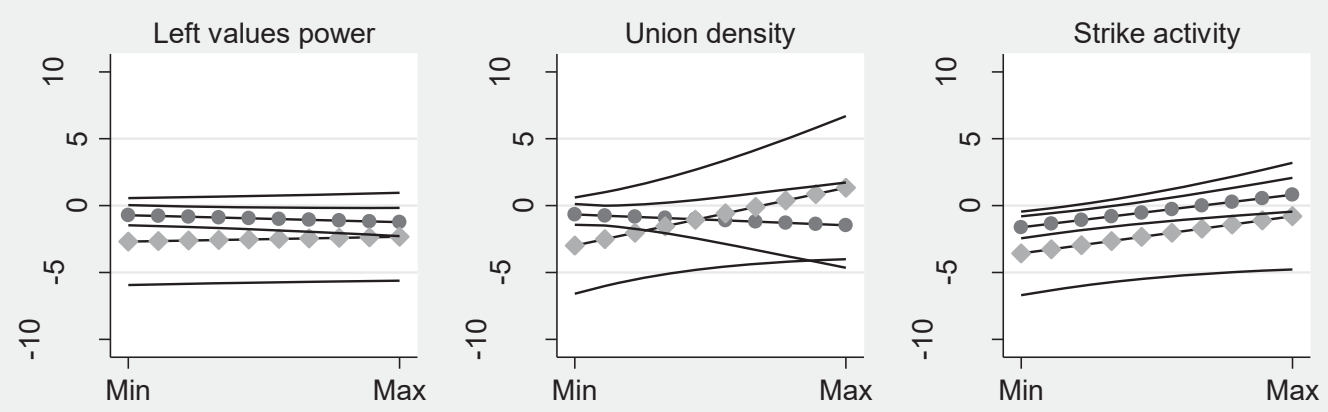

Note: Grey dots $=$ max. EPL, Black dots $=$ min. EPL. Black solid lines $=90 \%$ CFI. Full estimation results reported in Appendix Table 5. 
Appendix Table 1. Definition and source of variables

\begin{tabular}{|c|c|c|}
\hline Name & Definition & Source \\
\hline \multicolumn{3}{|l|}{ Dependent Variables } \\
\hline ALMP per GDP & Sum of Employment Assistance, Job creation, Training & $\begin{array}{l}\text { OECD SOCX } \\
(2011)\end{array}$ \\
\hline $\begin{array}{l}\text { ALMP per } \\
\text { unemployed (In) }\end{array}$ & $\begin{array}{l}\text { Logarithm of ALMP at constant prices (2000) in national currency, in } \\
\text { millions divided by unemployed persons }\end{array}$ & $\begin{array}{l}\text { OECD SOCX } \\
(2011), \text { OECD } \\
\text { LFS (2011) }\end{array}$ \\
\hline ALMP per PLMP & Sum of Employment Assistance, Job creation, Training & $\begin{array}{l}\text { OECD SOCX } \\
(2011)\end{array}$ \\
\hline \multicolumn{3}{|l|}{ Macro-Economic } \\
\hline GDP growth & Growth of real GDP, percentage change from previous year & $\begin{array}{l}\text { Armingeon et. } \\
\text { al. (2011) }\end{array}$ \\
\hline Deficit & Annual deficit (government primary balance) as a percentage of GDP & $\begin{array}{l}\text { Armingeon et. } \\
\text { al. (2011) }\end{array}$ \\
\hline Openness & $\begin{array}{l}\text { Openness of the economy in current prices, measured as total trade } \\
\text { (sum of import and export) as a percentage of GDP }\end{array}$ & $\begin{array}{l}\text { Armingeon et. } \\
\text { al. (2011) }\end{array}$ \\
\hline Unemployment Rate & Unemployment rate as a percentage of civilian labor force & $\begin{array}{l}\text { Armingeon et. } \\
\text { al. (2011) }\end{array}$ \\
\hline Time periods & $\begin{array}{l}\text { Period } 1=1986-90, \text { Period } 2=1991-95, \text { Period } 3=1996-00, \text { Period } 4= \\
2001-05\end{array}$ & \\
\hline \multicolumn{3}{|l|}{$\begin{array}{l}\text { Welfare Regime } \\
\text { Dummies }\end{array}$} \\
\hline Liberal & Australia, Canada, Ireland, New Zealand, UK, USA & \\
\hline Conservatives & Austria, Belgium, France, Germany, Netherlands, Switzerland & \\
\hline Northern & Denmark, Finland, Norway, Sweden & \\
\hline Southern & Italy, Portugal, Spain & \\
\hline \multicolumn{3}{|l|}{ Political Parties } \\
\hline \multirow[t]{3}{*}{ Left values power } & $\begin{array}{l}\text { Based on governments' right-left position (RILE) and composition of the } \\
\text { government. }\end{array}$ & $\begin{array}{l}\text { Armingeon et. } \\
\text { al. 2011, } \\
\text { Volkens et al }\end{array}$ \\
\hline & $\begin{array}{l}\text { Original right-left position (RILE) was reversed to range from -100 } \\
\text { (extreme right) to } 100 \text { (extreme left), and defined according to Laver and } \\
\text { Budge (1992). The formula reads as follows: (Military: Positive + } \\
\text { Freedom and Human Rights + Constitutionalism: Positive + Political } \\
\text { Authority + Free Market Economy + (Economic) Incentives + } \\
\text { Protectionism: Negative + Economic Orthodoxy + Welfare State } \\
\text { Limitation + National Way of Live: Positive + Traditional Morality: } \\
\text { Positive + Law and Order + Civil Mindedness) - (Anti-Imperialism + } \\
\text { Military: Negative + Peace + Internationalism: Positive + Democracy+ } \\
\text { Market Regulation + Economic Planning + Protectionism: Positive + } \\
\text { Controlled Economy + Nationalism + Welfare State Expansion + } \\
\text { Education Expansion + Labour Group: Positive) }\end{array}$ & $(2011)$ \\
\hline & $\begin{array}{l}\text { According to Armingeon et. al. (2011) left parties cabinet composition is } \\
\text { defined as social-democratic and other left parties in percentage of total } \\
\text { cabinet posts, weighted by days }\end{array}$ & \\
\hline \multicolumn{3}{|c|}{ 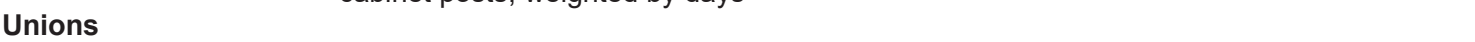 } \\
\hline Union density & Net union membership as $\%$ of wage and salary earners in employment & $\begin{array}{l}\text { Armingeon et. } \\
\text { al. (2011) }\end{array}$ \\
\hline Strikes (In) & $\begin{array}{l}\text { Logarithm of the index of strike activity, working days lost per } 1000 \\
\text { workers }\end{array}$ & $\begin{array}{l}\text { Armingeon et. } \\
\text { al. (2011) }\end{array}$ \\
\hline $\begin{array}{l}\text { Context dependence } \\
\text { EPL }\end{array}$ & $\begin{array}{l}\text { Strictness of employment protection on the basis of national legislation } \\
\text { (not collective agreements) covering permanent contracts, temporary } \\
\text { contracts, and collective dismissals }\end{array}$ & OECD (2010) \\
\hline
\end{tabular}


Appendix Table 2. Descriptive statistics

\begin{tabular}{|c|c|c|c|c|c|}
\hline Variable & Obs & Mean & Std. Dev. & Min & Max \\
\hline ALMP per GDP & 80 & 0.00 & 1.00 & -1.50 & 3.66 \\
\hline ALMP / Unempl. & 78 & 0.00 & 1.00 & -1.36 & 2.88 \\
\hline ALMP / PLM & 80 & 0.00 & 1.00 & -1.39 & 4.16 \\
\hline GDP growth & 80 & 0.00 & 1.00 & -2.28 & 4.66 \\
\hline Deficit & 80 & 0.00 & 1.00 & -2.46 & 2.92 \\
\hline Openness & 80 & 0.00 & 1.00 & -1.51 & 2.88 \\
\hline Unemployment rate & 80 & 0.00 & 1.00 & -1.81 & 3.53 \\
\hline Continental European & 76 & 0.32 & 0.47 & 0.00 & 1.00 \\
\hline Scandinavian & 76 & 0.21 & 0.41 & 0.00 & 1.00 \\
\hline Southern & 76 & 0.16 & 0.37 & 0.00 & 1.00 \\
\hline Left values power & 80 & 0.00 & 1.00 & -0.96 & 1.75 \\
\hline Union density & 80 & 0.00 & 1.00 & -1.42 & 2.26 \\
\hline Strike activity (In) & 80 & 0.00 & 1.00 & -2.72 & 1.63 \\
\hline EPL & 80 & 0.00 & 1.00 & -1.73 & 2.06 \\
\hline
\end{tabular}


Appendix Table 3. Regression analysis: ALMP spending per unemployed and as a share of PLMP spending

\begin{tabular}{|c|c|c|c|c|c|c|c|c|c|c|}
\hline & Model 1 & Model 2 & Model 3 & Model 4 & Model 5 & Model 6 & Model 7 & Model 8 & Model 9 & Model 10 \\
\hline & \multicolumn{5}{|c|}{ Dep. Var.: ALMP spending per unempl. (head) } & \multicolumn{5}{|c|}{ Dep. Var.: ALMP spending as share of PLMP spending } \\
\hline & BE & FE & FE & FE & $\mathrm{FE}$ & $\mathrm{BE}$ & FE & FE & FE & FE \\
\hline GDP growth & $\begin{array}{l}-0.048 \\
{[0.06]}\end{array}$ & $\begin{array}{c}-0.0137 \\
{[0.05]}\end{array}$ & $\begin{array}{c}-0.00661 \\
{[0.05]}\end{array}$ & $\begin{array}{c}-0.000397 \\
{[0.04]}\end{array}$ & $\begin{array}{c}-0.000799 \\
{[0.04]}\end{array}$ & $\begin{array}{l}0.131 \\
{[0.13]}\end{array}$ & $\begin{array}{c}0.0536 \\
{[0.13]}\end{array}$ & $\begin{array}{c}0.0722 \\
{[0.12]}\end{array}$ & $\begin{array}{c}0.0939 \\
{[0.11]}\end{array}$ & $\begin{array}{c}0.1 \\
{[0.11]}\end{array}$ \\
\hline Deficit & $\begin{array}{c}0.0317 \\
{[0.06]}\end{array}$ & $\begin{array}{c}-0.00983 \\
{[0.04]}\end{array}$ & $\begin{array}{c}-0.0124 \\
{[0.04]}\end{array}$ & $\begin{array}{c}-0.00746 \\
{[0.03]}\end{array}$ & $\begin{array}{c}-0.00875 \\
{[0.03]}\end{array}$ & $\begin{array}{l}0.0807 \\
{[0.13]}\end{array}$ & $\begin{array}{c}0.172^{* *} \\
{[0.08]}\end{array}$ & $\begin{array}{c}0.167^{* *} \\
{[0.08]}\end{array}$ & $\begin{array}{c}0.173^{* *} \\
{[0.08]}\end{array}$ & $\begin{array}{l}0.165^{*} \\
{[0.08]}\end{array}$ \\
\hline Openness & $\begin{array}{c}0.177^{* * *} \\
{[0.06]}\end{array}$ & $\begin{array}{c}-0.0235 \\
{[0.12]}\end{array}$ & $\begin{array}{c}-0.0333 \\
{[0.12]}\end{array}$ & $\begin{array}{c}-0.0745 \\
{[0.12]}\end{array}$ & $\begin{array}{c}-0.0872 \\
{[0.11]}\end{array}$ & $\begin{array}{c}0.0732 \\
{[0.13]}\end{array}$ & $\begin{array}{c}-0.0815 \\
{[0.36]}\end{array}$ & $\begin{array}{c}-0.103 \\
{[0.37]}\end{array}$ & $\begin{array}{c}-0.184 \\
{[0.37]}\end{array}$ & $\begin{array}{l}-0.224 \\
{[0.38]}\end{array}$ \\
\hline Unemployment rate & $\begin{array}{c}-0.204^{* * *} \\
{[0.05]}\end{array}$ & $\begin{array}{c}-0.259^{* * *} \\
{[0.04]}\end{array}$ & $\begin{array}{c}-0.270^{* * *} \\
{[0.05]}\end{array}$ & $\begin{array}{c}-0.235^{\star * *} \\
{[0.03]}\end{array}$ & $\begin{array}{c}-0.234^{* * *} \\
{[0.03]}\end{array}$ & $\begin{array}{c}-0.411^{* * *} \\
{[0.12]}\end{array}$ & $\begin{array}{c}-0.441^{* *} \\
{[0.19]}\end{array}$ & $\begin{array}{c}-0.467^{* *} \\
{[0.21]}\end{array}$ & $\begin{array}{c}-0.408^{* *} \\
{[0.14]}\end{array}$ & $\begin{array}{c}-0.423^{* *} \\
{[0.17]}\end{array}$ \\
\hline Conservative & $\begin{array}{c}0.233^{*} \\
{[0.14]}\end{array}$ & & & & & $\begin{array}{c}-0.0436 \\
{[0.31]}\end{array}$ & & & & \\
\hline Scandinavia & $\begin{array}{c}1.427^{\star \star *} \\
{[0.14]}\end{array}$ & & & & & $\begin{array}{c}0.775^{* *} \\
{[0.32]}\end{array}$ & & & & \\
\hline Southern & $\begin{array}{l}-0.177 \\
{[0.15]}\end{array}$ & & & & & $\begin{array}{c}0.853^{* *} \\
{[0.34]}\end{array}$ & & & & \\
\hline Left values power & & $\begin{array}{c}-0.0104 \\
{[0.02]}\end{array}$ & & & $\begin{array}{c}-0.0179 \\
{[0.01]}\end{array}$ & & $\begin{array}{c}-0.0324 \\
{[0.07]}\end{array}$ & & & $\begin{array}{c}-0.0375 \\
{[0.07]}\end{array}$ \\
\hline Union density & & & $\begin{array}{l}0.153 \\
{[0.18]}\end{array}$ & & $\begin{array}{c}-0.0346 \\
{[0.16]}\end{array}$ & & & $\begin{array}{l}0.431 \\
{[0.45]}\end{array}$ & & $\begin{array}{l}0.112 \\
{[0.43]}\end{array}$ \\
\hline Strike activity & & & & $\begin{array}{c}0.222^{* * *} \\
{[0.05]}\end{array}$ & $\begin{array}{c}0.231^{* * *} \\
{[0.05]}\end{array}$ & & & & $\begin{array}{c}0.480^{* * *} \\
{[0.15]}\end{array}$ & $\begin{array}{c}0.469^{* *} \\
{[0.18]}\end{array}$ \\
\hline $1991-95$ & & $\begin{array}{l}0.108 \\
{[0.08]}\end{array}$ & $\begin{array}{l}0.125 \\
{[0.07]}\end{array}$ & $\begin{array}{c}0.196^{* * *} \\
{[0.06]}\end{array}$ & $\begin{array}{c}0.199^{* * *} \\
{[0.06]}\end{array}$ & & $\begin{array}{c}0.0916 \\
{[0.17]}\end{array}$ & $\begin{array}{l}0.148 \\
{[0.19]}\end{array}$ & $\begin{array}{l}0.241 \\
{[0.16]}\end{array}$ & $\begin{array}{l}0.259 \\
{[0.18]}\end{array}$ \\
\hline $1996-00$ & & $\begin{array}{l}0.189 \\
{[0.13]}\end{array}$ & $\begin{array}{l}0.228^{*} \\
{[0.13]}\end{array}$ & $\begin{array}{c}0.337^{* * *} \\
{[0.10]}\end{array}$ & $\begin{array}{c}0.342^{* * *} \\
{[0.10]}\end{array}$ & & $\begin{array}{c}0.14 \\
{[0.26]}\end{array}$ & $\begin{array}{l}0.257 \\
{[0.30]}\end{array}$ & $\begin{array}{l}0.405^{*} \\
{[0.22]}\end{array}$ & $\begin{array}{l}0.444 \\
{[0.27]}\end{array}$ \\
\hline $2001-05$ & & $\begin{array}{l}0.164 \\
{[0.13]}\end{array}$ & $\begin{array}{l}0.226 \\
{[0.13]}\end{array}$ & $\begin{array}{c}0.365^{\star * *} \\
{[0.11]}\end{array}$ & $\begin{array}{c}0.363^{\star * *} \\
{[0.11]}\end{array}$ & & $\begin{array}{l}0.226 \\
{[0.36]}\end{array}$ & $\begin{array}{c}0.41 \\
{[0.44]}\end{array}$ & $\begin{array}{l}0.608^{*} \\
{[0.32]}\end{array}$ & $\begin{array}{l}0.656 \\
{[0.39]}\end{array}$ \\
\hline Observations & 74 & 78 & 78 & 78 & 78 & 76 & 80 & 80 & 80 & 80 \\
\hline Adjusted R-squared & 0.765 & 0.455 & 0.466 & 0.582 & 0.576 & 0.214 & 0.262 & 0.273 & 0.351 & 0.336 \\
\hline AIC & 79.55 & -58.4 & -59.99 & -79.1 & -76.26 & 207.5 & 130.6 & 129.4 & 120.3 & 123.8 \\
\hline $\mathrm{BIC}$ & 97.98 & -39.55 & -41.14 & -60.25 & -52.69 & 226.1 & 149.6 & 148.5 & 139.4 & 147.6 \\
\hline
\end{tabular}

Note: $\mathrm{BE}=$ Between countries effects, $\mathrm{FE}=$ Country fixed effects robust standard errors in brackets, ${ }^{*} \mathrm{p}<0.10,{ }^{* *} \mathrm{p}<0.05, * * * \mathrm{p}<0.001$, constant included but not reported. 
Appendix Table 4. Panel jackknife omitting one cross section at a time

\begin{tabular}{|c|c|c|c|c|c|c|}
\hline & Minimum & MinCS & Estimate & Maximum & MaxCS & Range \\
\hline \multicolumn{7}{|l|}{ Model 7 Table 3} \\
\hline GDP growth & -0.028 & 13 & 0.005 & 0.053 & 18 & 0.081 \\
\hline Deficit & -0.284 & 13 & -0.216 & -0.163 & 20 & 0.121 \\
\hline Openness & 0.104 & 15 & 0.176 & 0.266 & 11 & 0.162 \\
\hline Unemployment rate & 0.031 & 11 & 0.103 & 0.142 & 5 & 0.111 \\
\hline Left values power & -0.076 & 5 & -0.059 & -0.016 & 20 & 0.061 \\
\hline Union density & 0.433 & 20 & 0.626 & 0.72 & 7 & 0.287 \\
\hline Strike activity & 0.177 & 7 & 0.231 & 0.264 & 4 & 0.087 \\
\hline $1991-95$ & 0.308 & 17 & 0.365 & 0.403 & 19 & 0.095 \\
\hline $1996-00$ & 0.586 & 5 & 0.725 & 0.85 & 13 & 0.264 \\
\hline 2001-05 & 0.419 & 5 & 0.548 & 0.643 & 6 & 0.225 \\
\hline \multicolumn{7}{|c|}{ Model 5 Appendix Table 3} \\
\hline GDP growth & -0.03 & 13 & -0.003 & 0.032 & 18 & 0.062 \\
\hline Deficit & -0.043 & 13 & -0.017 & 0 & 5 & 0.043 \\
\hline Openness & -0.125 & 11 & -0.077 & 0.003 & 13 & 0.128 \\
\hline Unemployment rate & -0.316 & 19 & -0.278 & -0.26 & 11 & 0.056 \\
\hline Left values power & -0.028 & 19 & -0.013 & -0.008 & 1 & 0.019 \\
\hline Union density & 0.113 & 5 & 0.184 & 0.277 & 19 & 0.164 \\
\hline Strike activity & 0.114 & 13 & 0.14 & 0.163 & 3 & 0.049 \\
\hline 1991-95 & 0.155 & 1 & 0.188 & 0.22 & 19 & 0.065 \\
\hline 1996-00 & 0.277 & 5 & 0.34 & 0.388 & 19 & 0.111 \\
\hline 2001-05 & 0.283 & 5 & 0.358 & 0.402 & 19 & 0.119 \\
\hline \multicolumn{7}{|c|}{ Model 10 Appendix Table 3} \\
\hline GDP growth & 0.031 & 11 & 0.097 & 0.162 & 12 & 0.131 \\
\hline Deficit & 0.082 & 12 & 0.137 & 0.177 & 5 & 0.095 \\
\hline Openness & -0.28 & 11 & -0.146 & -0.031 & 3 & 0.249 \\
\hline Unemployment rate & -0.554 & 19 & -0.45 & -0.329 & 20 & 0.225 \\
\hline Left values power & -0.064 & 19 & -0.019 & 0.015 & 12 & 0.078 \\
\hline Union density & 0.052 & 20 & 0.237 & 0.365 & 5 & 0.314 \\
\hline Strike activity & 0.177 & 20 & 0.258 & 0.304 & 12 & 0.127 \\
\hline 1991-95 & 0.118 & 17 & 0.197 & 0.26 & 19 & 0.142 \\
\hline $1996-00$ & 0.266 & 12 & 0.358 & 0.431 & 19 & 0.164 \\
\hline 2001-05 & 0.393 & 12 & 0.535 & 0.646 & 6 & 0.254 \\
\hline
\end{tabular}

Note: Minimum $=$ Minimum Coefficient, MinCS $=$ Number of Cross Section Omitted at Minimum, Estimate $=$ Coefficient Estimate using all Cross Sections, Maximum = Maximum Coefficient, MaxCS = Number of Cross Section Omitted at Maximum. 
Appendix Table 5. Conditional effect of EPL on types of ALMP spending

\begin{tabular}{|c|c|c|c|c|c|c|c|c|c|}
\hline \multirow[b]{2}{*}{ GDP growth } & \multicolumn{3}{|c|}{ ALMP spending per GDP } & \multicolumn{3}{|c|}{ ALMP spending per unempl. (head) } & \multicolumn{3}{|c|}{ ALMP / PLM spending } \\
\hline & $\begin{array}{l}0.0819 \\
{[0.10]}\end{array}$ & $\begin{array}{l}0.0782 \\
{[0.08]}\end{array}$ & $\begin{array}{c}0.135^{\star *} \\
{[0.06]}\end{array}$ & $\begin{array}{l}0.0155 \\
{[0.05]}\end{array}$ & $\begin{array}{c}0.00528 \\
{[0.04]}\end{array}$ & $\begin{array}{c}0.0244 \\
{[0.03]}\end{array}$ & $\begin{array}{l}0.116 \\
{[0.14]}\end{array}$ & $\begin{array}{l}0.124 \\
{[0.12]}\end{array}$ & $\begin{array}{l}0.161 \\
{[0.11]}\end{array}$ \\
\hline Deficit & $\begin{array}{c}-0.210^{* *} \\
{[0.10]}\end{array}$ & $\begin{array}{c}-0.221^{* *} \\
{[0.08]}\end{array}$ & $\begin{array}{c}-0.238^{* * *} \\
{[0.06]}\end{array}$ & $\begin{array}{c}-0.00778 \\
{[0.04]}\end{array}$ & $\begin{array}{c}-0.0145 \\
{[0.03]}\end{array}$ & $\begin{array}{c}-0.0300 \\
{[0.03]}\end{array}$ & $\begin{array}{c}0.174^{* *} \\
{[0.08]}\end{array}$ & $\begin{array}{l}0.179^{*} \\
{[0.10]}\end{array}$ & $\begin{array}{l}0.177^{*} \\
{[0.10]}\end{array}$ \\
\hline Openness & $\begin{array}{c}-0.397 \\
{[0.29]}\end{array}$ & $\begin{array}{l}-0.299 \\
{[0.29]}\end{array}$ & $\begin{array}{c}-0.397^{*} \\
{[0.22]}\end{array}$ & $\begin{array}{l}-0.157 \\
{[0.13]}\end{array}$ & $\begin{array}{c}-0.0826 \\
{[0.13]}\end{array}$ & $\begin{array}{c}-0.100 \\
{[0.11]}\end{array}$ & $\begin{array}{c}-0.348 \\
{[0.60]}\end{array}$ & $\begin{array}{c}-0.264 \\
{[0.53]}\end{array}$ & $\begin{array}{c}-0.442 \\
{[0.57]}\end{array}$ \\
\hline Unemployment rate & $\begin{array}{c}0.0329 \\
{[0.12]}\end{array}$ & $\begin{array}{c}-0.0233 \\
{[0.12]}\end{array}$ & $\begin{array}{c}0.0732 \\
{[0.08]}\end{array}$ & $\begin{array}{c}-0.299^{\star * *} \\
{[0.05]}\end{array}$ & $\begin{array}{c}-0.300^{* * *} \\
{[0.05]}\end{array}$ & $\begin{array}{c}-0.254^{\star * *} \\
{[0.04]}\end{array}$ & $\begin{array}{c}-0.513^{* *} \\
{[0.24]}\end{array}$ & $\begin{array}{c}-0.414^{* *} \\
{[0.18]}\end{array}$ & $\begin{array}{c}-0.459^{* *} \\
{[0.20]}\end{array}$ \\
\hline EPL & $\begin{array}{c}-0.605^{\star *} \\
{[0.27]}\end{array}$ & $\begin{array}{c}-0.290 \\
{[0.27]}\end{array}$ & $\begin{array}{c}-0.444^{*} \\
{[0.22]}\end{array}$ & $\begin{array}{c}-0.219^{\star} \\
{[0.11]}\end{array}$ & $\begin{array}{c}-0.0935 \\
{[0.15]}\end{array}$ & $\begin{array}{c}-0.0274 \\
{[0.10]}\end{array}$ & $\begin{array}{l}-0.498 \\
{[0.80]}\end{array}$ & $\begin{array}{r}-0.595 \\
{[0.92]}\end{array}$ & $\begin{array}{c}-0.588 \\
{[0.70]}\end{array}$ \\
\hline Left values power & $\begin{array}{c}-0.0853 \\
{[0.06]}\end{array}$ & & & $\begin{array}{c}-0.0192 \\
{[0.02]}\end{array}$ & & & $\begin{array}{c}-0.0463 \\
{[0.08]}\end{array}$ & & \\
\hline Left values power $\times$ EPL & $\begin{array}{c}0.0262 \\
{[0.04]}\end{array}$ & & & $\begin{array}{c}0.0621^{* * *} \\
{[0.02]}\end{array}$ & & & $\begin{array}{c}0.0836 \\
{[0.12]}\end{array}$ & & \\
\hline Union density & & $\begin{array}{l}0.618^{*} \\
{[0.33]}\end{array}$ & & & $\begin{array}{c}0.0576 \\
{[0.17]}\end{array}$ & & & $\begin{array}{l}0.374 \\
{[0.67]}\end{array}$ & \\
\hline Union density $x \mathrm{EPL}$ & & $\begin{array}{l}-0.209 \\
{[0.27]}\end{array}$ & & & $\begin{array}{c}-0.0861 \\
{[0.12]}\end{array}$ & & & $\begin{array}{l}0.361 \\
{[0.41]}\end{array}$ & \\
\hline Strike activity & & & $\begin{array}{c}0.437^{* * *} \\
{[0.11]}\end{array}$ & & & $\begin{array}{c}0.187^{* * *} \\
{[0.05]}\end{array}$ & & & $\begin{array}{c}0.536^{* *} \\
{[0.22]}\end{array}$ \\
\hline Strike activity $\times$ EPL & & & $\begin{array}{c}-0.202^{* *} \\
{[0.09]}\end{array}$ & & & $\begin{array}{c}-0.127^{*} \\
{[0.06]}\end{array}$ & & & $\begin{array}{c}0.0475 \\
{[0.22]}\end{array}$ \\
\hline 1991-95 & $\begin{array}{c}0.344^{* *} \\
{[0.15]}\end{array}$ & $\begin{array}{c}0.415^{* * *} \\
{[0.13]}\end{array}$ & $\begin{array}{c}0.491^{* * *} \\
{[0.10]}\end{array}$ & $\begin{array}{l}0.132 \\
{[0.08]}\end{array}$ & $\begin{array}{l}0.130^{*} \\
{[0.07]}\end{array}$ & $\begin{array}{c}0.209^{* * *} \\
{[0.06]}\end{array}$ & $\begin{array}{l}0.150 \\
{[0.21]}\end{array}$ & $\begin{array}{l}0.149 \\
{[0.23]}\end{array}$ & $\begin{array}{l}0.306 \\
{[0.18]}\end{array}$ \\
\hline $1996-00$ & $\begin{array}{l}0.478^{*} \\
{[0.25]}\end{array}$ & $\begin{array}{c}0.690^{* *} \\
{[0.26]}\end{array}$ & $\begin{array}{c}0.728^{\star * *} \\
{[0.19]}\end{array}$ & $\begin{array}{l}0.155 \\
{[0.10]}\end{array}$ & $\begin{array}{l}0.188 \\
{[0.11]}\end{array}$ & $\begin{array}{c}0.316^{* * *} \\
{[0.08]}\end{array}$ & $\begin{array}{l}0.0733 \\
{[0.24]}\end{array}$ & $\begin{array}{l}0.134 \\
{[0.33]}\end{array}$ & $\begin{array}{l}0.352^{*} \\
{[0.20]}\end{array}$ \\
\hline 2001-05 & $\begin{array}{l}0.268 \\
{[0.23]}\end{array}$ & $\begin{array}{c}0.556^{* *} \\
{[0.22]}\end{array}$ & $\begin{array}{c}0.667^{* * *} \\
{[0.17]}\end{array}$ & $\begin{array}{l}0.150 \\
{[0.11]}\end{array}$ & $\begin{array}{l}0.174 \\
{[0.12]}\end{array}$ & $\begin{array}{c}0.365^{\star * *} \\
{[0.09]}\end{array}$ & $\begin{array}{l}0.196 \\
{[0.32]}\end{array}$ & $\begin{array}{l}0.316 \\
{[0.40]}\end{array}$ & $\begin{array}{l}0.583^{*} \\
{[0.29]}\end{array}$ \\
\hline Observations & 80 & 80 & 80 & 78 & 78 & 78 & 80 & 80 & 80 \\
\hline Adjusted R-squared & 0.335 & 0.386 & 0.533 & 0.535 & 0.491 & 0.660 & 0.281 & 0.310 & 0.373 \\
\hline AIC & 73.24 & 66.90 & 44.93 & -69.13 & -62.12 & -93.49 & 130.2 & 126.9 & 119.2 \\
\hline BIC & 97.06 & 90.72 & 68.75 & -45.57 & -38.55 & -69.92 & 154.0 & 150.7 & 143.0 \\
\hline
\end{tabular}

Note: Country fixed effects with robust standard errors in brackets, ${ }^{*} \mathrm{p}<0.10, * * \mathrm{p}<0.05, * * * \mathrm{p}<0.001$, constant included but not reported. 
www.celsi.sk

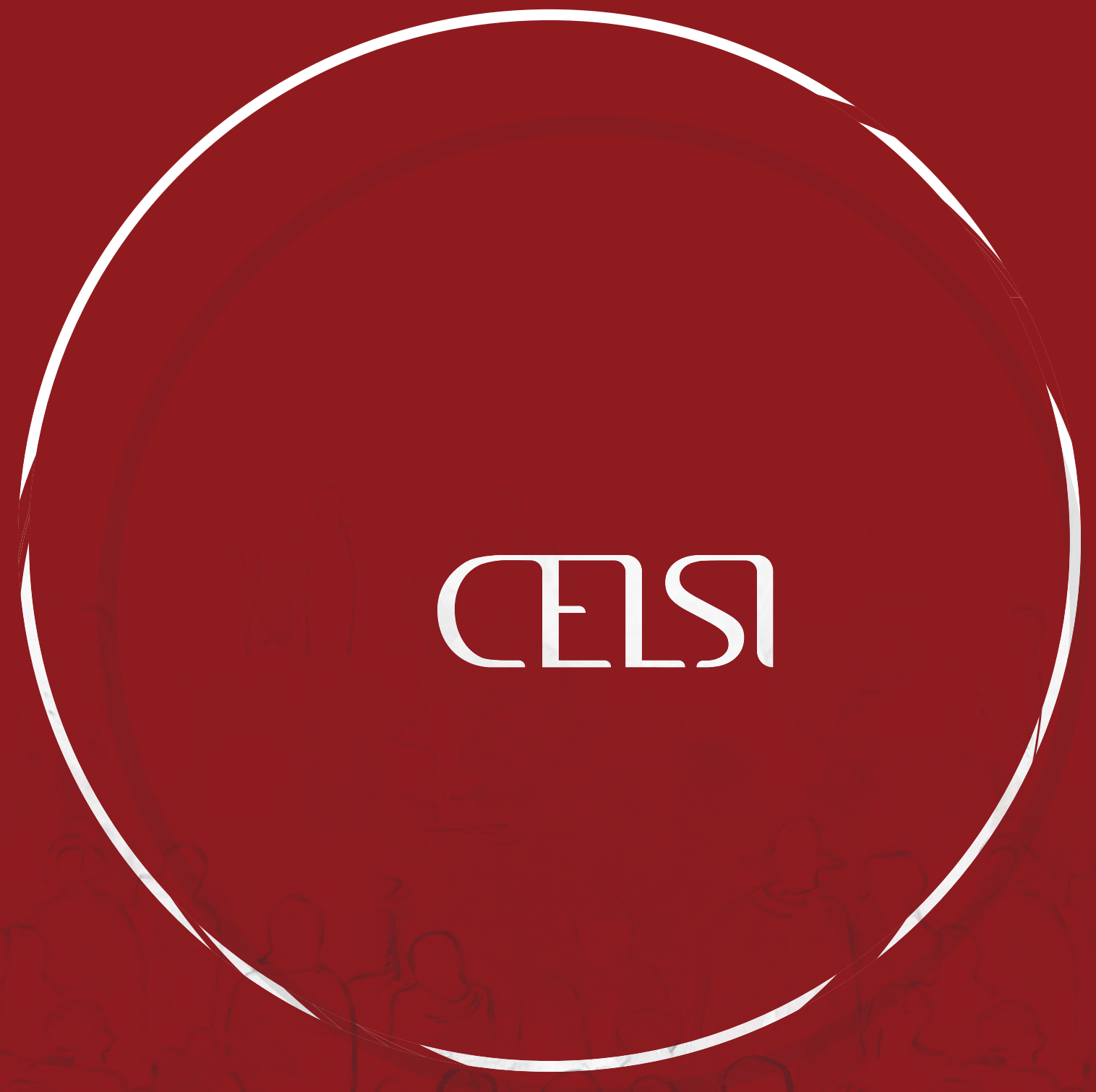

